\title{
Forging a Clearer Path Forward FOR ASSESSING CUMULATIVE IMPACTS ON Aboriginal AND Treaty Rights
}

\author{
DiAnA Audino, STEPHANIE AXMANN, \\ BRYN GRAY, KIM HOWARD, AND LJILJANA STANIC*
}

\begin{abstract}
Project reviews have become the primary forum to discuss cumulative impacts of energy and resource development on Aboriginal and treaty rights. After thoroughly reviewing the case law and legislation, the authors assert that these impacts cannot be resolved through piecemeal measures like individual permitting decisions. Governments need to use broader actions such as effective land-use planning, regional assessments, and separate forums to address specific concerns with at-risk species. Further, clear policy and regulatory guidelines must be created with careful attention to promoting responsible development and avoiding stifling investment in Canada. By doing so, governments will be in a better position to consider environmental, Aboriginal rights, and treaty rights issues while establishing certainty for project proponents.
\end{abstract}

\section{TABLE OF CONTENTS}

I. INTRODUCTION . . . . . . . . . . . . . . . . . . . . . . . . . . . . . 298

II. OVERVIEW OF THE CROWN'S DUTY TO CONSUlt . . . . . . . . . . . . . 299

III. The Role of Cumulative Impacts In the Duty to Consult . . . . . 302

A. Cumulative Impacts Resulting from Past Activities $\ldots \ldots 302$

B. Future CuMULATIVE IMPACTS

BEyond the CROWN DeCISION AT ISSUE $\ldots \ldots \ldots \ldots \ldots \ldots . \ldots$

C. ACCOMMODATION RELATING TO CUMULATIVE IMPACTS $\ldots \ldots .311$

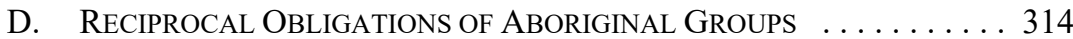

IV. TREATY Rights InFRINGEMENT Claims $\ldots \ldots \ldots \ldots \ldots \ldots \ldots \ldots \ldots$

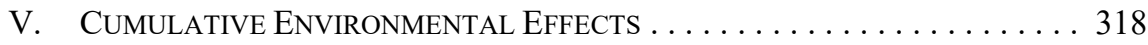

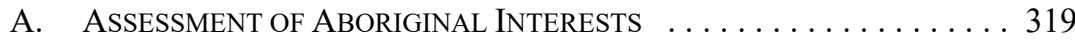

B. ASSESSMENT OF CUMULATIVE ENVIRONMENTAL EFFECTS . . . . . 322

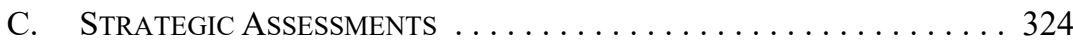

VI. OUtstanding IsSUES AND CHARTING A BetTER PATH ForWARD $\ldots \ldots 330$

A. UtilizATION OF LAND-USE PlanNing AND REGIONAL ASSESSMENTS . . . . . . . . . . . . . . . 330

B. ADDRESSING ABORIGINAL CONCERNS OUTSIDE OF THE Consultation And Project Review Setting . . . . . . . . . . 332

C. Clearer Guidance from Government TO FILL IN KNOWLEDGE GAPS . . . . . . . . . . . . . . . 332

D. RECOMMENDATIONS FOR PROPONENTS FOR CONSIDERING

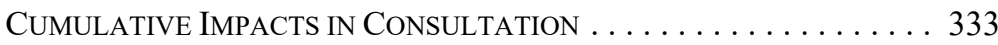

Diana Audino is a Senior Legal Counsel at Enbridge, and Stephanie Axmann, Bryn Gray, Kim Howard, and Ljiljana Stanic are lawyers at McCarthy Tétrault LLP. The authors gratefully acknowledge the assistance of Stephanie Willsey and Amelia Martin. 


\section{INTRODUCTION}

The assessment of cumulative impacts on Aboriginal $^{1}$ and treaty rights has become a frequently raised concern and challenge in energy and resource development project reviews across Canada. This issue most often arises in regions where there has been substantial development and Aboriginal groups are concerned that their ability to exercise their rights will be further impaired by a proposed project. Project review processes have become a central forum to discuss cumulative impact concerns, but they generally lack the appropriate tools needed to address an issue that goes beyond individual projects. Most Aboriginal groups want cumulative impacts to be addressed in a more comprehensive way outside of project-related consultation and processes to stop the effects of what is often called "death by a thousand cuts." 2 Proponents are also dissatisfied with the current approach. They often struggle with how to assess and address cumulative impacts when such concerns are raised in project reviews, owing to a general lack of guidance and unclear division of roles and responsibilities as between proponents and governments.

Currently, proponents of energy and resource development projects may be required to consider cumulative impacts on Aboriginal and treaty rights in two situations: (1) when the duty to consult is triggered, and (2) if required by legislation such as environmental assessment (EA) legislation in certain Canadian jurisdictions. The requirements in either situation are notably different, including the scope of what needs to be considered and addressed. In our view, neither is currently equipped to properly address the issue of cumulative impacts due to their respective inherent limitations and general lack of guidance. A clearer and more comprehensive path forward is needed.

This article reviews how the assessment of cumulative impacts on Aboriginal and treaty rights has been considered in Canadian jurisprudence, how it compares to the assessment of cumulative environmental effects, and how it could be improved going forward. In Part II, we provide an overview of the relevant principles of the Crown's duty to consult. In Part III, we discuss how cumulative impacts on Aboriginal and treaty rights have been treated in duty-to-consult jurisprudence and the guidance that has emerged to date. In Part IV, we discuss treaty rights infringement claims, which some Aboriginal groups are pursuing to address past cumulative impacts. In Part V, we compare the courts' consideration of cumulative impacts on Aboriginal and treaty rights with the consideration of cumulative environmental effects in EAs and project reviews, including a discussion of how the requirements are poised to change under new or proposed legislation by the British Columbia and federal governments, respectively. In Part VI, we conclude with our recommendations for a better path forward on this challenging issue and questions for proponents to keep in mind when faced with concerns about cumulative impacts on Aboriginal and treaty rights.

We have used the term "Aboriginal" in this article when referring to Aboriginal rights given the language used in section 35 of the Constitution Act, 1982, being Schedule B to the Canada Act 1982 (UK), 1982, c 11. We have also used the term "Aboriginal" when referring collectively to First Nations, Inuit, and Métis but have used these individual terms, as appropriate, when referring to individual groups that are First Nations, Inuit, or Métis.

See e.g. Re Manitoba Hydro (November 2018), EH-001-2017 at 3, online: NEB <apps.neb-one.gc.ca/ REGDOCS/File/Download/3700925> [Manitoba Hydro]; Yellowknives Dene First Nation v Canada (Minister of Aboriginal Affairs and Northern Development), 2013 FC 1118, aff'd 2015 FCA 148 at para 10 [Yellowknives]; Dene Tha' First Nation v British Columbia (Minister of Energy and Mines), 2013 BCSC 977 at para 94 [Dene Tha']. 


\section{OVERVIEW OF THE CROWN's DUTY TO CONSUlT}

It is necessary to have a basic familiarity with the duty to consult and its relevant principles in order to understand the scope of cumulative impact concerns that may need to be considered and addressed when the duty to consult is triggered.

Since 2004, the Supreme Court of Canada has repeatedly confirmed that the Crown has a duty to consult and potentially accommodate affected Aboriginal groups whenever it contemplates conduct that may adversely impact asserted or established Aboriginal or treaty rights. ${ }^{3}$ The Crown's duty applies to asserted but unproven rights and rights agreed to in historic and modern treaties or otherwise established through the courts. ${ }^{4}$ It is a constitutional duty that is grounded in the honour of the Crown and is an obligation of the government as a whole. While consultation is not itself a right under section 35 of the Constitution Act, 1982, it is a key tool used to further the "grand purpose" of section 35, which the Supreme Court has stated is the "reconciliation of Aboriginal and non-Aboriginal Canadians in a mutually respectful long-term relationship."

The threshold to trigger the duty to consult is low. ${ }^{6}$ All that is needed is a Crown decision with the potential to adversely impact asserted or established Aboriginal or treaty rights. ${ }^{7}$ However, the potential adverse impact must be appreciable or discernible and cannot be speculative. ${ }^{8}$ Past wrongs, including prior and continuing breaches of the duty to consult (including prior failures to consult), will only trigger the duty if the current government decision in question (including strategic, higher-level decisions) has the potential of causing a novel adverse impact on a present claim or existing right. ${ }^{9}$

If the duty to consult is triggered, the level of consultation required in a given situation is contextual and proportionate to a preliminary assessment of the strength of the claim and the seriousness of the potential impact of the proposed government action on the right claimed..$^{10}$ What may be required in any given situation falls along a spectrum. At the lower end, where

See e.g. Haida Nation v British Columbia (Minister of Forests), 2004 SCC 73 [Haida]; Taku River Tlingit First Nation v British Columbia (Project Assessment Director), 2004 SCC 74 [Taku River]; Mikisew Cree First Nation v Canada (Minister of Canadian Heritage), 2005 SCC 69 [Mikisew Cree 2005]; Ktunaxa Nation v British Columbia (Forests, Lands and Natural Resource Operations), 2017 SCC 54 [Ktunaxa]. The Supreme Court of Canada set out the overall framework for the duty to consult in Haida and Taku River and extended it to include asserted Aboriginal rights. Prior to Haida, the Supreme Court discussed a duty to consult in certain contexts relating to established Aboriginal rights. See e.g. $R v$ Sparrow, [1990] 1 SCR 1075 at 1119; $R v$ Nikal, [1996] 1 SCR 1013 at paras 109-10; $R v$ Gladstone, [1996] 2 SCR 723 at paras 55, 64; Delgamuukw v British Columbia, [1997] 3 SCR 1010 at para 168. [Mikisew Cree]; Beckman v Little Salmon/Carmacks First Nation, 2010 SCC 53 at paras 61, 67-69 [Beckman].

Beckman, ibid at para 10 .

Mikisew Cree, supra note 4 at para 34.

For a discussion of what constitutes the "Crown" for the purposes of the duty to consult, see Clyde River (Hamlet) v Petroleum Geo-Services Inc, 2017 SCC 40 at paras 28-29 [Clyde River].

$8 \quad$ Rio Tinto Alcan Inc v Carrier Sekani Tribal Council, 2010 SCC 43 at para 46 [Rio Tinto]; Hupacasath First Nation v Canada (Minister of Foreign Affairs), 2015 FCA 4 at paras 88, 102, 106; Fort Nelson First Nation v British Columbia (Environmental Assessment Office), 2016 BCCA 500 at para 121 [Fort Nelson]; Buffalo River Dene Nation v Saskatchewan (Minister of Energy and Resources), 2015 SKCA 31 at paras 90-91; Fort Chipewyan Métis Nation of Alberta Local \#125 v Alberta, 2016 ABQB 713 at para 91. 
the claim is weak and the impacts will be minor, the Crown may only be required to give notice, provide information, and discuss issues raised in response. At the higher end, where the claim is strong or there are established rights and the impacts will be significant, deep consultation may be required, which may entail the opportunity to make submissions and participate in the decision-making process, accommodation, and the provision of written reasons. $^{11}$

The focus of the constitutional duty to consult is on impacts to rights, not impacts to Aboriginal peoples generally or environmental effects per se. While impacts to rights are often caused by environmental effects, consultation is intended to be rights-focused and not an afterthought to an EA. ${ }^{12}$ That said, proponents may be required to assess other impacts to Aboriginal peoples beyond what is required under the duty to consult in order to comply with legislated EA and permitting requirements.

In practice, there is often a disconnect between the expectations of Aboriginal groups for a certain level of consultation and what is required at common law. In some cases, this may be a result of historical or legacy concerns with development in a particular area, which may not have undergone consultation. However, the Supreme Court has confirmed that the subject of consultation is limited to the impact on rights flowing from the current Crown decision, not the prior adverse impacts of a project. ${ }^{13}$ As will be discussed, this does not mean that prior impacts and concerns about cumulative impacts beyond the individual project can be disregarded; rather, they may assist to inform the required depth of consultation and accommodation. ${ }^{14}$

Regardless of the level of consultation required, the courts have repeatedly emphasized that consultation must be meaningful and conducted in good faith. ${ }^{15}$ The Crown must consult with an open mind and make genuine efforts to understand and address concerns about impacts to Aboriginal or treaty rights before making a decision. Consultation may reveal a duty to accommodate, but this is not a stand-alone duty and is not required in all instances. Accommodation typically entails taking steps to avoid irreparable harm, as well as mitigating or minimizing the effects of a government action or decision on the Aboriginal interests at stake.

The Crown is afforded significant flexibility in how it meets the duty to consult, and it can rely, in whole or in part, on regulatory or EA processes to fulfill its duty to consult and, where appropriate, accommodate. ${ }^{16}$ However, if the regulatory or EA process does not provide for adequate consultation or accommodation, the Crown must take further measures to fulfill its duty either on a case-by-case basis or through broader reforms to the processes being relied upon. ${ }^{17}$ The Crown must act reasonably; it is not held to a standard of perfection

Ibid.

Clyde River, supra note 7 at paras 45,51 .

Rio Tinto, supra note 8 at para 49.

Chippewas of the Thames First Nation v Enbridge Pipelines Inc, 2017 SCC 41 at paras 41-42 [Chippewas of the Thames].

Haida, supra note 3 at para 42; Chartrand v British Columbia (Forests, Lands and Natural Resource Operations), 2015 BCCA 345 at para 77; Chippewas of the Thames, ibid at para 2.

Taku River, supra note 3 at para 40; Chippewas of the Thames, ibid at para 1; Clyde River, supra note 7 at para 22.

Clyde River, ibid at para 22. 
in assessing the adequacy of consultation, and mistakes, misunderstandings, and omissions may occur. ${ }^{18}$

While the duty to consult ultimately rests with the Crown, it may delegate procedural aspects of the duty to industry proponents. ${ }^{19}$ In practice, governments have to date tended to rely heavily on industry for consultation and accommodation. ${ }^{20}$

The courts have repeatedly held that consultation is a two-way street and Aboriginal groups have reciprocal obligations to participate in good faith and cannot frustrate reasonable good faith efforts by imposing unreasonable conditions or refusing to participate. They must raise concerns early and with specificity. ${ }^{21}$

The Supreme Court has confirmed that the process of consultation does not provide any guarantee that the specific accommodation sought by an Aboriginal group will be warranted or possible. It is a right to a process, not an outcome, and there must be give and take on all sides. ${ }^{22}$ Competing societal interests can be balanced or reconciled with Aboriginal or treaty rights during the accommodation stage. ${ }^{23}$ The courts have repeatedly held that Aboriginal groups do not have a "veto" over final Crown decisions, nor is there a duty to agree. ${ }^{24}$

Over the last several years, many Aboriginal groups have taken the position that both proponents and the Crown must obtain their free, prior, and informed consent for any decisions affecting their asserted or established Aboriginal or treaty rights. This is based, in part, on certain provisions in the United Nations Declaration on the Rights of Indigenous Peoples, ${ }^{25}$ which to date has not been adopted into Canadian law. ${ }^{26}$ Both the federal and British Columbia governments have indicated that they intend to implement UNDRIP. Their implementation efforts and public comments to date suggest that they intend to generally interpret the principle of "free, prior and informed consent" as an objective rather than an absolute requirement for consent. ${ }^{27}$ However, British Columbia's current provincial

Gitxaala Nation $v$ R, 2016 FCA 187 at paras 8, 182-83 [Gitxaala].

Haida, supra note 3 at para 53; Chippewas of the Thames, supra note 14 at para 51.

Haida, ibid.

Ktunaxa, supra note 3; Michipicoten First Nation v Minister of Natural Resources and Forests, 2016 ONSC 6899.

Haida, supra note 3 at para 48.

Chippewas of the Thames, supra note 14 at paras 41-42; Gitxaala, supra note 18 at paras $179-80$; Haida, supra note 3 at paras 42, 47-48, 62 .

$24 \quad$ Haida, ibid at para 48; Mikisew Cree 2005, supra note 3 at para 66; Beckman, supra note 4 at para 14; Chippewas of the Thames, supra note 14 at para 59; Ktunaxa, supra note 3 at para 80.

GA Res 61/295, UNGAOR, 61st Sess, Supp No 53, UN Doc A/61/53 (2007) [UNDRIP].

Bill C-262, An Act to ensure the laws of Canada are in harmony with the United Nations Declaration on the Rights of Indigenous Peoples, 1st Sess, 42nd Parl, 2018 (as passed by the House of Commons 30 May 2018) was passed by the House of Commons and subsequently died on the order paper in the Senate prior to the 2019 federal election. This was a private member's bill that the current federal government initially opposed but subsequently supported. If passed, it would have affirmed UNDRIP as a universal international human rights instrument with application in Canadian law and required the federal government to take all measures necessary to ensure the laws of Canada are consistent with UNDRIP.

27 UNDRIP, supra note 25, art 11(2). The new British Columbia Environmental Assessment Act, which will come into force through Bill 51, Environmental Assessment Act, 3rd Sess, 41st Leg, British Columbia, 2018 (third reading 26 November 2018) [New BC EAA], specifies two instances where the consent of Aboriginal groups is required: (i) on treaty lands if the final agreement with the Aboriginal group requires consent or (ii) in an area that is subject to an agreement between an Aboriginal group and the British Columbia government that requires this consent (ss 7(a)-(b)). These situations are not new and existed before this legislation. Separate and apart from this legislation, the British Columbia government has indicated its willingness to enter into agreements with Aboriginal groups where consent 
government has in certain cases required the consent of First Nations. ${ }^{28}$ Even outside such case-by-case situations, these commitments suggest that there will likely be greater scrutiny by the federal and British Columbia governments on consultation and accommodation and efforts to achieve consent.

\section{The Role of Cumulative ImPaCtS IN THE DUTY TO CONSULT}

The Supreme Court of Canada has confirmed that, if the duty to consult is triggered, past cumulative impacts and the historical context may inform the scope of the duty to consult. While the Supreme Court has not provided further guidance on this issue, the decisions of lower courts and tribunals indicate that cumulative impacts on Aboriginal and treaty rights may serve to deepen the level of consultation required and may give rise to a duty to accommodate with respect to avoiding or offsetting additional incremental and cumulative impacts from the Crown decision at issue. However, it is not a certainty that cumulative impacts from past or historic developments will always demand a deeper level of consultation and accommodation. They may in fact have the opposite effect if the proposed project is located on a brownfield site and there will be minimal-to-no additional anticipated impacts on Aboriginal or treaty rights.

Duty-to-consult jurisprudence indicates that the key cumulative impacts to be considered are the combination of past impacts and impacts flowing from the current Crown decision at issue. Future anticipated impacts of the particular project beyond the current Crown decision have limited-to-no relevance to the analysis, and the anticipated impacts of other planned developments are currently outside the scope of the duty to consult. The scope of future anticipated impacts that need to be considered is more narrow than what must be taken into account in a cumulative environmental effects assessment, which considers cumulative effects from all existing and reasonably foreseeable projects. Below is a summary of the key jurisprudence to date that has considered cumulative impacts in the context of the duty to consult.

\section{A. Cumulative Impacts Resulting FROM PAST ACTIVITIES}

There have been several key decisions that have considered the relevance of past impacts (cumulative or otherwise) on Aboriginal or treaty rights within the duty-to-consult framework. This includes most notably the Supreme Court of Canada's decisions in Rio Tinto and Chippewas of the Thames, the British Columbia Court of Appeal's decision in

is required such as for the renewal of fish farm licences on Vancouver Island. It remains to be seen whether the British Columbia government will enter into similar arrangements relating to other activities or areas of the province. 
West Moberly, and the British Columbia Supreme Court's decision in Adams Lake Indian Band $v$ British Columbia (Ministry of Forests, Lands and Natural Resource Operations). ${ }^{29}$

Together, these cases establish that past impacts are not on their own capable of triggering the duty to consult and that, if the duty to consult is triggered by a new decision, the focus of consultation is on the impacts flowing from the present Crown decision at issue. However, past and cumulative impacts may still be relevant to understanding the impact of the current Crown decision. This is because the degree of impact cannot be determined in a vacuum and past cumulative impacts may make the impact of the decision at issue more significant than it would be if it were only viewed in isolation.

\section{RIO TINTO}

The Supreme Court of Canada's 2010 decision in Rio Tinto v. Carrier Sekani Tribal Council is a seminal case addressing the relevance of past impacts in the duty to consult and the scope of future impacts that may need to be considered.

This case arose from a challenge to the British Columbia Utilities Commission's approval of a 2007 Energy Purchase Agreement (EPA) between Alcan (now Rio Tinto Alcan) and BC Hydro for the sale of excess power from the Kenney Dam in northern British Columbia. Potentially affected First Nations ${ }^{30}$ were not consulted prior to the construction of the dam in the 1950s or before the EPA was signed. The dam and reservoir altered the water flow of a river that the Carrier Sekani Tribal Council First Nations traditionally used for fishing and sustenance, but the EPA itself would not impact the water flows and water levels or alter the management structure of the reservoir. There was uncontroverted evidence that Alcan would continue to produce electricity at the same rates regardless of whether the 2007 EPA was approved and it would sell its power elsewhere if BC Hydro did not buy it. ${ }^{31}$

In Rio Tinto, the Supreme Court held that the "subject of the consultation is the impact on the claimed rights of the current decision under consideration" and "not [the] larger adverse impacts of the project of which it is a part." 32 The Supreme Court also held that past wrongs and historical grievances do not in and of themselves trigger the duty to consult. Rather, there must be a novel adverse impact arising from the current decision for the duty to consult to arise:

The question is whether there is a claim or right that potentially may be adversely impacted by the current government conduct or decision in question. Prior and continuing breaches, including prior failures to consult, will only trigger a duty to consult if the present decision has the potential of causing a novel adverse impact on a present claim or existing right. This is not to say that there is no remedy for past and continuing breaches, including previous failures to consult. As noted in Haida Nation, a breach of the duty to consult may be remedied in various ways, including the awarding of damages. To trigger a fresh duty of consultation

2013 BCSC 877 [Adams Lake].

As noted above, we are using the term "First Nations" rather than Aboriginal when referring to individual First Nations or groups that only comprise First Nations.

Rio Tinto, supra note 8 at paras 12, 92.

Ibid at para 53 [emphasis in original]. 
- the matter which is here at issue - a contemplated Crown action must put current claims and rights in jeopardy. $^{33}$

Applying these principles to the facts, the Supreme Court found that it was reasonable for the British Columbia Utilities Commission to conclude that the EPA did not create any novel adverse impacts to Aboriginal or treaty rights and that the duty to consult was not triggered. The Supreme Court's finding that consultation is confined to the adverse impacts flowing from the specific Crown proposal at issue was initially interpreted by some to mean that cumulative impacts - whether past or future - do not ever need to be considered in consultation. However, shortly after the release of Rio Tinto, the British Columbia Court of Appeal clarified in West Moberly First Nations v. British Columbia (Chief Inspector of Mines) ${ }^{34}$ that past cumulative impacts can still be relevant if the duty to consult is triggered.

\section{WEST MOBERLY}

In West Moberly First Nations v. British Columbia (Chief Inspector of Mines), the West Moberly First Nations (WMFN) challenged decisions by the British Columbia government to amend certain permits granted to a proponent for advanced exploration for coal mining on the basis that the permits adversely affected their treaty right to hunt caribou. The permit amendments would authorize activity in an area of fragile caribou habitat, and the WMFN argued that there was insufficient provision made for the protection and restoration of the Burnt Pine caribou herd, which at that time only comprised 11 remaining caribou. The WMFN are party to Treaty 8 , which guarantees its First Nation signatories the "right to pursue their usual vocations of hunting, trapping and fishing throughout the tract surrendered." 35

Both the British Columbia Supreme Court and the British Columbia Court of Appeal found that the British Columbia government did not fulfill the duty to consult prior to granting the permit amendments. On appeal to the British Columbia Court of Appeal, the proponent argued that the chambers judge erred by inter alia considering the historical decline of the Burnt Pine caribou herd and, in doing so, was purporting to redress "past wrongs" contrary to Rio Tinto. ${ }^{36}$ The majority of the British Columbia Court of Appeal found that the chambers judge did not err in considering the historical decline of the Burnt Pine caribou herd, as past impacts can be relevant and may provide important context if the duty to consult has been triggered. Chief Justice Finch distinguished this situation from Rio Tinto (where the duty was not triggered), stating:

I do not understand Rio Tinto to be authority for saying that when the "current decision under consideration" will have an adverse impact on a First Nations right, as in this case, that what has gone before is irrelevant. Here, the exploration and sampling projects will have an adverse impact on the petitioners' treaty right, and the historical context is essential to a proper understanding of the seriousness of the potential impacts on the petitioners' treaty right to hunt.

Ibid at para 49 [emphasis in original].

2011 BCCA 247 [West Moberly].

Ibid at para 53.

Ibid at para 8 . 
To take those matters into consideration as within the scope of the duty to consult, is not to attempt the redress of past wrongs. Rather, it is simply to recognize an existing state of affairs, and to address the consequences of what may result from pursuit of the exploration programs. ${ }^{37}$

The reasons of all three judges acknowledged that decisions like this are not made in a vacuum and that in this case, past impacts could not be ignored. However, each judge made it clear that, consistent with Rio Tinto, this did not amount to a right of redress for such past impacts, and that the consideration of past impacts does not mean those impacts have to be reversed or redressed as part of the consultation process. ${ }^{38}$

\section{ADAMS LAKE}

In Adams Lake Indian Band v. British Columbia (Ministry of Forests, Lands and Natural Resource Operations), the British Columbia Supreme Court further clarified how past and cumulative impacts may need to be considered in consultation when the duty to consult is triggered. In this case, Adams Lake Indian Band challenged the issuance of two licences that would permit a ski resort to add eight runs and one lift to an existing development in the British Columbia interior and, relying on West Moberly, raised concerns about cumulative impacts on their rights.

In his reasons, Justice Fenlon underscored the limited purpose of considering past impacts in fulfilling the duty to consult:

\footnotetext{
The crux of [the West Moberly] decision was that the impact of the additional exploration on caribou habitat had to be assessed in the context of previous destruction of habitat, not as if the rest of the habitat was untouched wilderness... Applied to the case at bar, West Moberly suggests that the loss of additional treed areas on Mount Morrissey must be considered in the context of the overall area already lost to resort development. That is quite different from considering all past impacts.
}

Second, the inclusion of past impacts within the scope of the duty to consult is inconsistent with the purpose for which the duty was designed: "to prevent damage to Aboriginal claims and rights while negotiations are underway".... If the damage has already occurred, it cannot by definition be prevented. Past wrongs are to be addressed in other ways. ${ }^{39}$

This decision reinforces the limited scope of examination of past cumulative impacts within the duty to consult. Past impacts need to be understood as part of the present state of affairs. However, these past impacts do not need to be addressed within the consultation process as the duty to consult is forward-looking and aimed at avoiding or minimizing further impacts from the specific Crown decision at issue. 


\title{
4. CHIPPEWAS OF THE THAMES
}

The Supreme Court of Canada recently addressed the issue of cumulative impacts in its 2017 decision, Chippewas of the Thames. ${ }^{40}$ This case stemmed from the National Energy Board's (NEB) approval of an application for changes to the existing Line 9 pipeline in Ontario pursuant to section 58 of the National Energy Board Act. ${ }^{41}$ As the project affected already-disturbed lands, the NEB held that the impacts of the project would be minimal and likely to be appropriately mitigated.

In considering the scope of the duty to consult, the Supreme Court reaffirmed its findings in Rio Tinto that the duty to consult is focused on the impacts from the current decision under consideration and that the duty to consult is not triggered by historical impacts nor is it a vehicle to address historical wrongs, grievances, or the "broader claims that transcend the scope of the proposed project." 42

However, the Supreme Court acknowledged with reference to West Moberly that historical context and cumulative impacts can be relevant in consultation, albeit for a limited purpose:

\footnotetext{
The duty to consult is not triggered by historical impacts. It is not the vehicle to address historical grievances. In [Rio Tinto], this Court explained that the Crown is required to consult on "adverse impacts flowing from the specific Crown proposal at issue - not [on] larger adverse impacts of the project of which it is a part. The subject of the consultation is the impact on the claimed rights of the current decision under consideration" ([Rio Tinto], at para. 53 (emphasis in original)). [Rio Tinto] also clarified that "[a]n order compelling consultation is only appropriate where the proposed Crown conduct, immediate or prospective, may adversely impact on established or claimed rights" (para. 54).
}

\begin{abstract}
That said, it may be impossible to understand the seriousness of the impact of a project on s. 35 rights without considering the larger context (J. Woodward, Native Law (loose-leaf), vol. 1, at pp. 5-107 to 5-108). Cumulative effects of an ongoing project, and historical context, may therefore inform the scope of the duty to consult (West Moberly First Nations v. British Columbia (Chief Inspector of Mines), 2011 BCCA 247, 18 B.C.L.R. (5th) 234, at para. 117). This is not "to attempt the redress of past wrongs. Rather, it is simply to recognize an existing state of affairs, and to address the consequences of what may result from" the project (West Moberly, at para. 119). ${ }^{43}$
\end{abstract}

\section{SumMary OF PRINCIPLES FOR CUMUlative IMPACTS FROM PAST ACTIVITIES}

In Chippewas of the Thames, the Supreme Court of Canada did not provide guidance on the precise role of cumulative impacts from past activities in consultation and accommodation. However, there are some clear takeaways about the role of cumulative impacts in consultation from the above-referenced cases. 
First, cumulative impacts and the historical context may have the effect of deepening the level of consultation required if the duty to consult is triggered, as they may magnify the impact of the specific decision at issue. The taking-up of Crown land for a project development is a good example of this issue. The taking-up of a small amount of land in a large treaty area on its own may be seen as a low impact since affected Aboriginal groups can theoretically exercise any harvesting rights elsewhere. However, if the land were one of the few remaining pieces of Crown land available to exercise harvesting rights, the impact is likely much more significant, requiring more in-depth consultation. As stated by Justice Grauer in Taseko Mines Limited v. Phillips: "Each new incursion serves only to narrow further the habitat left to them in which to exercise their traditional rights. Consequently, each new incursion becomes more significant than the last." ${ }^{, 44}$

Second, the fact that past impacts can be relevant if the duty to consult is triggered does not mean that prior decisions can be challenged, ${ }^{45}$ that past wrongs need to be redressed, ${ }^{46}$ or that proponents and governments need to study the individual causes or contributors to these various past impacts. Rather, they need to understand the practical effects that these impacts have had on the exercise of Aboriginal or treaty rights and what additional incremental impacts the current project or proposal will have. For example, in West Moberly, the Crown did not need to understand all of the historic impacts on the caribou but simply the additional impact that further exploration would have in the context of previously destroyed habitat.

Third, statutory mandates of decision-makers cannot be used as a justification to limit the scope of what needs to be considered when the duty to consult is triggered. It matters not that a statutory decision-maker is not empowered to consider cumulative impacts if these impacts at issue are within the jurisdiction of the government making the decision (such as the federal or provincial Crown). As stated by the British Columbia Court of Appeal in West Moberly, "[i]t is a well established principle that statutory decision makers are required to respect legal and constitutional limits. The Crown's duty to consult lies upstream of the statutory mandate of decision makers." 47

The failure to consider cumulative impacts on Aboriginal or treaty rights as a result of limits of statutory mandates can result in a breach of the duty to consult and the quashing of the approval at issue. There are several examples of this, including the British Columbia Supreme Court's 2017 decision in The Fort Nelson First Nation v. BC Oil and Gas Commission. ${ }^{48}$ In this case, the approval to construct and operate a pipeline and storage facility in Fort Nelson First Nation (FNFN) traditional territory was quashed after the BC Oil and Gas Commission (BCOGC) refused requests by FNFN to engage on certain issues, including cumulative impacts on their treaty right to hunt caribou and mitigation options not enforceable under the BCOGC regulatory framework. ${ }^{49}$

2011 BCSC 1675 at para 65.

William v British Columbia (Attorney General), 2019 BCCA 74 at para 70.

Chippewas of the Thames, supra note 14 at para 42.

West Moberly, supra note 34 at para 106.

2017 BCSC 2500.

Ibid at paras 37-38, 84-85. In Chippewas of the Thames, supra note 14, and Clyde River, supra note 7 , the Supreme Court of Canada affirmed that the Crown can rely in whole or in part on regulatory processes to fulfill the duty to consult. However, where the regulatory process being relied upon does not achieve adequate consultation or accommodation, the Crown must take further measures to meet the 
Fourth, concerns relating to past cumulative impacts will not have the same degree of relevance in all cases. For example, the relevance of cumulative impacts tends to be greater in situations where Crown land is being taken up, in comparison to projects located on private land where Aboriginal rights (such as hunting) are not being exercised. In certain circumstances, cumulative impacts from past activities can justify a reduced level of consultation. An example of this is where developments occur on previously disturbed, brownfield lands, and Aboriginal rights are not being exercised. Generally, with all other contextual factors being equal, a comparatively lower level of consultation will be required at law in respect of changes to a project operating on brownfield lands as compared to construction of a similar project on greenfield, previously undisturbed lands. However, even if there is an absence of Aboriginal traditional land-use on proposed project lands, a range of adverse impacts on Aboriginal rights and interests can still extend beyond the boundaries of such lands. Off-site impacts (like traffic, water, and air pollution) could still contribute to cumulative impacts on hunting of vulnerable species.

These principles demonstrate why the duty to consult is not and will never be a sufficient tool to address cumulative impacts on Aboriginal and treaty rights. While its forward-looking focus is appropriate given the purpose of the duty to consult, this is a source of frustration for many Aboriginal groups who want to rectify past cumulative impacts. These impacts may be from prior Crown decisions where there was no consultation or decisions that did not trigger the duty to consult because there was no underlying Crown decision. This, along with the limited scope of consideration of future cumulative impacts discussed below, highlights why other measures need to be developed outside the duty to consult and individual project reviews so that this issue can be addressed in a more comprehensive way.

\section{B. Future CUMUlative ImpaCts Beyond THE CROWN DECISION AT ISSUE}

The relevance of cumulative impacts resulting from future decisions and activities has been less thoroughly canvassed by the courts than past cumulative impacts. However, the general principles of the duty to consult suggest that consideration should not be given to future impacts beyond the specific decision at issue, whether these are impacts from future approvals relating to the same project or other reasonably anticipated projects. ${ }^{50}$ There may be an obligation to consider these impacts in an EA, but there are important reasons to be mindful of distinctions between EA requirements and the duty to consult, as will be discussed below.

As noted above, the Supreme Court of Canada confirmed in Rio Tinto that the subject matter of consultation is limited to the impact of the current decision under consideration on asserted or established Aboriginal or treaty rights. The Supreme Court revisited this issue in 2017 in Chippewas of the Thames and upheld the limited scope of consultation, which

duty to consult either on a case-by-case basis, through legislative or regulatory amendments, or through other measures such as making submissions to the regulatory body, requesting reconsideration of a decision, or seeking a postponement to allow for further consultation in a separate process before the decision is reached.

$50 \quad$ Rio Tinto, supra note 8 at para 53; Blueberry River First Nations v British Columbia (Natural Gas Development), 2017 BCSC 540 at para 72. 
effectively excludes other projects and other future Crown approvals associated with the same project, although some lower courts take a more relaxed view on the latter. This is another key inherent limitation of the duty-to-consult framework in addressing cumulative impacts. Aboriginal groups are frequently concerned about the totality of future development in their traditional territories and associated cumulative impacts and need a better forum to advance and address these issues outside of individual project reviews and the duty to consult.

Courts have affirmed that this incremental approach to consultation is appropriate in a regulatory process involving multiple Crown decisions. ${ }^{51}$ This principle was first articulated by the Supreme Court of Canada in 2004 in Taku River, ${ }^{52}$ the companion decision to Haida. The Supreme Court noted that the granting of a project approval certification was only one stage in the process by which a development moves forward, and that there would be opportunities for further consultation at later stages. The Supreme Court found that it was open to the Project Committee and applicable Ministers to determine what accommodation of the First Nation's concerns was warranted at that stage in the process, and what later opportunities for consultation would be appropriate:

\footnotetext{
The Project Committee concluded that some outstanding TRTFN [(Taku River Tlingit First Nation)] concerns could be more effectively considered at the permit stage or at the broader stage of treaty negotiations or land use strategy planning... The Project Committee, and by extension the Ministers, therefore clearly addressed the issue of what accommodation of the TRTFN's concerns was warranted at this stage of the project, and what other venues would also be appropriate for the TRTFN's continued input. It is expected that, throughout the permitting, approval and licensing process, as well as in the development of a land use strategy, the Crown will continue to fulfill its honourable duty to consult and, if indicated, accommodate the TRTFN. ${ }^{53}$
}

However, the fact that consultation will be undertaken at a later stage in connection with subsequent project approvals does not vitiate the Crown's duty to consult with respect to an earlier decision in a project approval process. If the duty to consult is triggered, the Crown is expected to engage in consultation from the earliest phases of a project in order for it to be meaningful. ${ }^{54}$ Courts have also held that the Crown cannot defer consultation such that a project becomes a foregone conclusion or fait accompli before being subject to comprehensive consultation and consideration at the appropriate phase. ${ }^{55}$

There have been some notable exceptions to this incremental approach in the context of future project approvals. In West Moberly, the then Chief Justice Finch opined that, when the decisions at issue are preliminary steps in an ongoing project, some consideration of future impacts resulting from those decisions is necessary in order for the consultation process to paras 93-100 [Louis CA].

Supra note 3.

Ibid at para 46.

Louis CA, supra note 51 at paras 104-106.

See also Sambaa K'e Dene Band v Duncan, 2012 FC 204, in which the Court noted that if consultation is to be meaningful, it "cannot be postponed until the last and final point in a series of decisions" (at para 165). 
be meaningful and to truly consider the protection of Aboriginal and treaty rights as the project moves forward. He explained with regard to the exploratory permits at issue:

On my reading of the chambers judge's reasons, it does not appear that he gave much, if any, weight to the potential impact of a full mining operation as a relevant factor in the Crown's duty to consult. However, the whole thrust of the petitioners' position was forward looking. It wanted to preserve not only those few animals remaining in the Burnt Pine caribou herd, but to augment and restore the herd to a condition in which it might once again be hunted. If that position were to be given meaningful consideration in the consultation process, I do not see how one could ignore at least the possibility of a full mining operation, if it were shown to be justified by the exploration programs. That was the whole object of the Bulk Sampling and Advanced Exploration Programs.

I am therefore respectfully of the view that to the extent the chambers judge considered future impacts, beyond the immediate consequences of the exploration permits, as coming within the scope of the duty to consult, he committed no error. And, to the extent that MEMPR [the Ministry of Energy, Mines and Petroleum Resources] failed to consider the impact of a full mining operation in the area of concern, it failed to provide meaningful consultation. ${ }^{56}$

In Adams Lake, the British Columbia Supreme Court attempted to reconcile the approach taken in West Moberly, suggesting that a consideration of future impacts was relevant only in cases where the decision was a preliminary one taken in service of a broader project, rather than a discrete construction or task:

And what of future impacts? The petitioner asserts that the two licences in issue are part of an inevitable train of events that will culminate in more development at the base of the mountain. They argue therefore that the impact of that development falls within the scope of consultation.

In my view, the future impacts of the decision in issue are distinguishable from the future impacts considered in West Moberly and Haida Nation. West Moberly involved permits for exploration, the object of which was future mining development. Similarly, in Haida Nation the purpose of the grant of tree farm licences was to allow logging to occur. In the instant case, the licences will authorize the creation of ski runs and a chair lift. They are an end in themselves, not merely a necessary step before a resource can be exploited. ${ }^{57}$

The British Columbia Supreme Court concluded that the province's decision to limit the scope of consultation to the effects of the current decision and exclude future impacts from consideration was reasonable and correct, considering the particular licence decisions in issue.

Despite some discrepancies between cases, the general principles of incremental consultation continue to hold. Further, we have not identified a court decision in which a describes the consultation process as essentially forward looking in reference to West Moberly and Mikisew. 
consideration of impacts from other reasonably anticipated projects is required under the duty to consult, as is the case with cumulative environmental effects assessments. ${ }^{58}$

\section{ACCOMmodation Relating to CuMulative IMPACTS}

Rio Tinto sets out the principle that consultation is not the appropriate forum to address historic grievances, and by extension, we argue that accommodation measures should not be used to remedy past impacts or issues outside the scope of the current project. That said, several recent decisions indicate that greater accommodation measures may be required if there are existing cumulative impacts that are affecting the ability of Aboriginal groups to exercise their Aboriginal or treaty rights and the current project will further contribute to these impacts in a material and adverse way. In these cases, proponents may be required to offset their actions to ensure that there is no net increase in adverse effects. In other words, the focus is on avoiding or offsetting any additional adverse impact rather than taking steps to minimize adverse impacts.

\section{WESTCOAST ENERGY}

In Re Westcoast Energy Inc., Westcoast Energy Inc. (Westcoast) applied to construct and operate the Wyndwood Pipeline Expansion Project, a 27-kilometre pipeline expansion in northeastern British Columbia. ${ }^{59}$ Affected Aboriginal groups presented the NEB with evidence regarding cumulative impacts on the exercise of Aboriginal and treaty rights, with special reference to the impacts on the caribou population and the right to hunt. In light of uncontroverted evidence on cumulative impacts, the NEB concluded that the proposed project was in the public interest but that Westcoast was required to ensure that the project would have a net neutral impact by offsetting any adverse impacts:

[T] he Board is of the view that given the already substantial ongoing cumulative effects on the landscape and on caribou in the region due to both direct and indirect habitat disturbance, all residual effects on caribou habitat should be considered and fully compensated. The Board expects Westcoast to offset all potential direct and indirect residual effects of the Project in order to ensure no net loss of caribou habitat and no incremental increase in adverse cumulative effects on cumulative habitat. ${ }^{60}$

See National Energy Board, National Energy Board Reconsideration of Aspects of its OH-001-2014 Report as Directed by Order in Council PC 2018-1177 (NEB, February 2019), MH-052-2018, online: $<$ apps.neb-one.gc.ca/REGDOCS/File/Download/3754859> [NEB Reconsideration Decision]. In the NEB Reconsideration Decision for the Trans Mountain pipeline, the NEB made recommendations to the federal government to address cumulative impacts on the Salish Sea beyond the project-related shipping because the issue required a "broad, systemic, and multi-faceted approach" (ibid at 4, 41). However, this recommendation is focused on cumulative impacts on the Salish Sea, not cumulative impacts on Aboriginal or Treaty rights.

59 (September 2017), GH-001-2017, online: NEB <apps.neb-one.gc.ca/REGDOCS/File/Download/333 7330> [Westcoast Energy]. Ibid at 114 . 
The NEB notably also called on industrial and commercial developers in northeastern British Columbia to develop a regional plan to address cumulative impacts with or without the British Columbia government:

The Board is cognizant of the pressures associated with the pace of development in northeast $\mathrm{BC}$ and has heard these concerns across a number of proceedings held in the region over the past few years. In GH-0012014, the Board heard concerns over cumulative effects in the region and appreciated that a regional plan would be highly beneficial in addressing these. At that time, the Board also recognized the need to establish acceptable thresholds of change, which could be used for subsequent project-specific assessments in the same geographic region.

The frustration felt by residents of this region is not new nor, in the minds of the residents, has it been addressed. The Board agrees with this assessment. Unfortunately, however sympathetic the Board is to the frustrations expressed, development of such a plan is beyond the scope of an NEB hearing.

The Board appeals, therefore, to the sense of corporate social responsibility shared by all industrial and commercial developers in this region. These corporations are encouraged to take the initiative to jointly develop such a plan either within or without BC government programs. The Board hopes that the time frame to develop this plan would be measured in months and not years or decades. The Board further hopes that the final product would be an updateable, integrated and forward looking, publically available plan which provides a necessary context for understanding and mitigating the cumulative impacts of all development leading to a comprehensible strategy for required landform rehabilitation and flora/fauna recovery. ${ }^{61}$

\section{MANITOBA HYDRO}

In Manitoba Hydro, the NEB imposed a requirement that the proponent develop an offset measures plan to address cumulative impact concerns raised by Aboriginal groups. ${ }^{62}$ In this case, Manitoba Hydro (a Crown corporation) applied to construct and operate a new international power line and make modifications to existing international and intra-provincial transmission lines and other associated transmission facilities. Manitoba Hydro proposed to take up Crown land for a 36-kilometre right-of-way in an area of the province where Crown land suitable to exercise treaty and Aboriginal rights was indicated to be in short supply. ${ }^{63}$ The NEB heard from several intervenors that the adjudication of large energy infrastructure projects felt like "death by a thousand cuts," wherein each new project (perhaps reasonable in itself) added another "cut" with no apparent opportunity to mitigate the ongoing cumulative impacts of these cuts. ${ }^{64}$ Manitoba Hydro took the position that the quantity of land being taken up for the project was very small in comparison with the total land available, and that land was still available for traditional use. The NEB did not accept this position and ordered the proponent to develop a Crown Land Offset Plan that details how the 
permanent loss of Crown lands available for traditional use by Aboriginal Peoples from the Project will be offset or compensated for:

In evaluating the right of the Crown to reduce the amount of land available to practice Treaty Rights and enter into other negotiations, the Board does well to accommodate impacts on Indigenous rights by following the Hippocratic policy of "primum non nocere" or, "first, do no harm"; that is, do no harm to the honour of the Crown by impeding its ability to fulfill its obligations. In other words, the proponent must establish a plan to offset or compensate the loss of Crown lands available for traditional use by Indigenous Peoples. ${ }^{65}$

\section{TRANS MOUNTAIN}

In its recent reconsideration decision for the Trans Mountain project, the NEB addressed the issue of cumulative impacts on the Salish Sea and the southern resident killer whale, an endangered species. The NEB found that while the incremental addition to cumulative impacts from project-related shipping would not be large, it would be adding to already significant impacts. To address these broader impacts, the NEB recommended to the federal government that it develop and implement a regional cumulative effects management plan to assess the environmental state of and cumulative effects on the Salish Sea and to develop a long-term strategy to manage those effects. The NEB also recommended that the government report annually on the status of this initiative and the measures to address cumulative effects on the Salish Sea. ${ }^{66}$

In the Trans Mountain reconsideration decision, the NEB went further than in Manitoba Hydro and Westcoast Energy and recommended that the federal government take additional steps to address cumulative impacts on the Salish Sea beyond the individual project, although this was not specifically focused on cumulative impacts on Aboriginal and treaty rights. ${ }^{67}$ The recommendation relating to the regional cumulative effects management plan does not specifically mention cumulative impacts on Aboriginal or treaty rights, but it is recommended that this plan be developed and implemented in consultation with Aboriginal peoples. The Trans Mountain decision is unique since the federal government is wearing two hats as the Crown and project proponent.

Based on these decisions, as cumulative impacts increase with increased development and taking-up of land, it may become more common for proponents to be ordered to ensure that their projects do not worsen conditions or further hamper the exercise of Aboriginal or treaty rights. This underscores the need for proponents to proactively consider offset measures where there are significant cumulative impact concerns that will be further exacerbated by a project.

We note that in each of the above-noted cases, the facts are dealing with new impacts from a new project. We are not aware of any case to date where the court has considered accommodation relating to cumulative impacts caused by an existing project that requires a further approval triggering the duty to consult. However, case law suggests that any 
accommodation should be related to avoiding additional novel adverse impacts and not addressing past impacts as there are other potential avenues for redress.

\section{RECIPROCAL OBLIGATIONS OF Aboriginal Groups}

One of the issues not yet specifically addressed to date by the courts is the reciprocal obligations of Aboriginal groups when raising cumulative impact concerns. However, based on existing law, it is expected that the reciprocal obligations would include the need to raise any cumulative impact concerns early and with specificity. In Ktunaxa Nation, the Supreme Court of Canada recently reiterated the reciprocal obligations of Aboriginal groups in consultation:

The Aboriginal group is called on to facilitate the process of consultation and accommodation by setting out its claims clearly (Haida Nation, at para. 36) and as early as possible.

The duty to consult and, if appropriate, accommodate the Aboriginal interest is a two-way street. The obligations on the Crown are to provide notice and information on the project, and to consult with the Aboriginal group about its concerns. The obligations on the Aboriginal group include: defining the elements of the claim with clarity ... not frustrating the Crown's reasonable good faith attempts; and not taking unreasonable positions to thwart the Crown from making decisions or acting where, despite meaningful consultation, agreement is not reached. ${ }^{68}$

The courts have also repeatedly held that in order to allege inadequate consultation, Aboriginal groups must present some evidence to establish an adverse impact on a credible claim to land or the rights being asserted. Mere submissions, generalities, or complaints of a general nature regarding the potential impacts on an Aboriginal or treaty right are not a sufficient basis upon which to allege a failure to consult. ${ }^{69}$ Where there are cumulative impact concerns, this underscores the need for Aboriginal groups to clearly identify what asserted or established rights are being exercised in the vicinity of the project, how these rights have been affected by cumulative impacts, and how these rights will be further impacted by the project.

To date, decision-makers have adopted varying approaches with respect to the level of information that Aboriginal groups need to provide when raising cumulative impact concerns, based in part on their statutory powers. Distinctions between the approaches adopted by the NEB and the Alberta Energy Regulator (AER) highlight this issue. In cases like Westcoast Energy and Manitoba Hydro, the NEB appears to have accepted assertions of cumulative impacts on Aboriginal and treaty rights without detailed evidence of those 
impacts and the use of the lands at issue. The AER, on the other hand, generally requires much more detailed evidence on cumulative impacts on Aboriginal or treaty rights than the NEB. The AER, which is statutorily precluded from assessing the adequacy of consultation, ${ }^{70}$ will not generally take steps to supplement the information provided to it by Aboriginal groups. For example, in Re Prosper Petroleum Ltd. Rigel Project, the AER indicated that the Fort McKay Métis Community Association (Fort McKay Métis), in raising cumulative impact concerns, had failed to produce sufficient evidence to demonstrate that cumulative impacts would affect the exercise of their Aboriginal rights over the area at issue:

\begin{abstract}
This panel must consider the impacts of the project that is before us. We can consider the significance of project-specific impacts in the context of cumulative effects of existing and planned development. However, there is insufficient evidence before us to inform us about how the lands that will be taken up by the Prosper Rigel project are or have been used by Fort McKay Métis. We cannot fully evaluate the significance of the impact of the Rigel project on Fort McKay Métis' Aboriginal rights. That is the case whether we consider the Rigel project as a standalone project or in the context of the accumulated impacts of existing and planned projects.
\end{abstract}

To be clear, that does not mean that we find that the Prosper lease lands do not have value to Fort McKay Métis. The panel finds they do have value to Fort McKay Métis. The evidence leads us to conclude that industrial activity on the lands comprising the Prosper lease might cause members of the community to value/perceive the lands and the resources the lands support differently than they do now. That is a negative social effect. But we cannot conclude based on the evidence before us that the Rigel project will prevent Fort McKay Métis from continuing to exercise its Aboriginal rights in its traditional territory. ${ }^{71}$

More specifically, the AER held that the concerns raised and evidence led by the Fort McKay Métis related more generally to development and projects in the area at issue, in which a number of oil sands exploration operations were occurring, rather than to the particular project under consideration. ${ }^{72}$ As a result, it held that the Fort McKay Métis had failed to demonstrate that the additional incremental impacts attributable to the project at issue would affect the exercise of its asserted Aboriginal rights. ${ }^{73}$

The Fort McKay Métis sought leave to appeal, submitting in part that the AER incorrectly placed the evidentiary burden on it to establish that the project at issue would affect its asserted Aboriginal rights. ${ }^{74}$ The Alberta Court of Appeal held that the Fort McKay Métis was best placed to explain and establish the claimed impact on its rights. ${ }^{75}$ It further found that the AER's findings with regard to sufficiency of evidence were findings of fact or mixed

Responsible Energy Development Act, SA 2012, c R-17.3, s 21.

Re Prosper Petroleum Ltd. Rigel Project (12 June 2018), 2018 ABAER 005 at paras 83-84, online: AER $<$ aer.ca/documents/decisions/2018/2018-ABAER-005.pdf> [Prosper Petroleum]. See also Re TransCanada Pipelines Limited Applications for the White Spruce Pipeline Project Fort McKay Area (22 February 2018), 2018 ABAER 001 at para 71, online: AER < aer.ca/documents/decisions/2018/ 2018ABAER001.pdf $>$ : "We find that concerns about cumulative effects on treaty and aboriginal rights raised by Fort McKay are general in nature and not supported by evidence specific enough to allow us to make direct findings of impact or give meaningful direction to eliminate or mitigate such alleged effects."

Prosper Petroleum, ibid at paras 74, 79, 81 .

Ibid at paras $73,75,78-79,82$.

Fort McKay Métis Community Association v Alberta Energy Regulator, 2019 ABCA 15 at para 37 [Fort McKay Métis].

Ibid at para 39. 
fact and law, rather than law, and were therefore not subject to appeal. ${ }^{76}$ The Alberta Court of Appeal dismissed this application for leave to appeal although the Fort McKay Métis are currently seeking leave to appeal to the Supreme Court of Canada.

\section{Treaty Rights InfRingement Claims}

Before discussing the consideration of cumulative impacts in EAs, it is important to note that some Aboriginal groups are also advancing cumulative impact concerns through treaty infringement claims. These claims are typically based on the premise that the cumulative impacts of the projects and industrial development in the respective Aboriginal groups' traditional territory have deprived them of their ability to meaningfully exercise treaty rights to the point of infringement. Blueberry River First Nations in British Columbia, Beaver Lake Cree First Nation in Alberta, and Carry the Kettle First Nation in Saskatchewan, parties to the Numbered Treaties, are each advancing similar ongoing claims of this nature.

While some Aboriginal groups are pursuing such claims, this is not a viable way for many Aboriginal groups to address cumulative impact concerns given the cost of litigation, the evidentiary threshold that must be met, and the uncertainty as to how the courts will deal with such claims. Infringement is a distinct legal doctrine that has largely been developed through case law relating to prosecutions of Aboriginal individuals for hunting and fishing offences. It is separate from the duty to consult and is generally engaged at a higher threshold of impacts. The duty to consult is triggered by a Crown decision that has the potential to adversely impact asserted or established rights. Infringement can only arise in situations where there are established rights (already recognized or proven in the proceedings) and it requires more than the potential for an adverse impact on a right. It requires a "meaningful diminution of the right," which takes into account the characteristics and incidents of the right at issue, and looks at whether the action in question (1) is unreasonable, (2) imposes undue hardship, and (3) denies the rights-holders their preferred means of exercising the right. ${ }^{77}$ In the context of taking up land in a treaty area where this is contemplated under the treaty, the Supreme Court of Canada has held that a potential action for infringement will arise where the impacts on rights by the taking-up of lands leaves the Aboriginal group without the ability to meaningfully exercise a right. ${ }^{78}$ Once an infringement is proven, the onus is on the Crown to justify the infringement. It must demonstrate that (1) it complied with its procedural duty to consult and accommodate, (2) the government action is backed by a compelling and substantial legislative objective, and (3) the government action is consistent with the Crown's fiduciary duty to the group. ${ }^{79}$

76 Ibid at para 40.

Tsilhqot'in Nation v British Columbia, 2014 SCC 44 at para 122 [Tsilhqot'in Nation]. See also Grassy Narrows First Nation v Ontario (Natural Resources), 2014 SCC 48 at para 52 [Grassy Narrows]. Grassy Narrows, ibid at para 52: "[I]f the taking up leaves the Ojibway with no meaningful right to hunt, fish or trap in relation to the territories over which they traditionally hunted, fished, and trapped, a potential action for treaty infringement will arise"; Mikisew Cree 2005, supra note 3 at para 48 [emphasis in original]:

If the time comes that in the case of a particular Treaty 8 First Nation "no meaningful right to hunt" remains over its traditional territories, the significance of the oral promise that "the same means of earning a livelihood would continue after the treaty as existed before it" would clearly be in question, and a potential action for treaty infringement, including the demand for a Sparrow justification, would be a legitimate First Nation response. 
The most advanced infringement claim based on cumulative impacts is that of Blueberry River First Nations (BRFN). This claim against the British Columbia government alleges that British Columbia has breached its obligations under Treaty 8 owing to the cumulative impacts of provincially authorized resource development throughout BRFN's traditional territory, resulting in BRFN's members being unable to exercise their traditional practices as intended by Treaty $8 .{ }^{80}$ BRFN seeks interim and permanent relief against all resource development that infringes its Treaty 8 rights.

BRFN asserts that the First Nation adherents to Treaty 8 consented to open up their lands based on assurances of their continued rights to carry on traditional and economic livelihoods by hunting, trapping, and fishing. However, they allege that British Columbia's authorizations of land alienation, resource extraction, and industrial activities in BRFN's traditional territory were made without regard to the impacts over time on BRFN's treaty rights. BRFN claims that such cumulative impacts have caused significant damage to the forests, air, lands, waters, plants, fish, and wildlife that are integral to BRFN's mode of life, and have reduced access to its traditional territory, resulting in an impoverishment of its members' mode of life. BRFN asserts that the extent of development has now reached the point of infringement, whereby BRFN's members have lost their ability to meaningfully pursue and exercise their treaty rights. A 2016 land-use study by Ecotrust Canada concluded that 73 percent of BRFN's traditional territory is within 250 metres of an industrial disturbance and 84 percent is within 500 metres of an industrial disturbance. This includes roadways, transmission lines, pipelines, and active petroleum and natural gas tenures, with 19,974 oil and gas wells in BRFN's traditional territory, of which 36 percent are active. ${ }^{81}$

Pending trial and resolution of its claim, BRFN has twice applied unsuccessfully for interlocutory injunctive relief against particular resource development activities in its traditional territory. ${ }^{82}$ The trial for BRFN's claim has also been adjourned on several occasions. During this time, there have been discussions between British Columbia and BRFN about resolving the claim and the development of interim measures to address the BRFN's concerns. These interim measures were designed to manage development activities in specified areas and prohibit or restrict new surface disturbance in certain defined critical areas of BRFN's traditional territory. In particular, the interim measures preclude further applications by industry proponents in two of three identified areas in BRFN territory. In the third identified area, new surface disturbance is restricted and may only occur if certain conditions are met. There is limited publicly available information about the implementation of the interim measures although discussions with the British Columbia government did reach an impasse and the trial commenced on 27 May $2019 .{ }^{83}$ files/news articles/2015-03-03\%20Notice $\% 20$ of $\% 20$ Civil $\% 20$ Claim.PDF>.

81 Eliana Macdonald, Atlas of Cumulative Landscape Disturbance in the Traditional Territory of Blueberry River First Nations, 2016 (Vancouver: Ecotrust Canada, 2016), online: <ecotrust.ca/wp-content/uploads/ 2016/06/EcotrustCanadaDSF BlueberryRiverAtlas.pdf $>$.

82 Yahey v British Columbia, 2015 BCSC 1302; Yahey v British Columbia, 2017 BCSC 899.

83 Shawn McCarthy, "Blueberry River First Nation Back in Court to Fight B.C. over Forestry, Oil and Gas Impact," The Globe and Mail (24 May 2019), online: <theglobeandmail.com/business/industry-news/ energy-and-resources/article-blueberry-river-first-nation-back-in-court-to-fight-bc-over-forestry/>. 
It is difficult to speculate on the ultimate chance of success of this case given the limited level of publicly available information. If it proceeds and is successful, it could set an important precedent for other Aboriginal groups across Canada (treaty and non-treaty) that could also consider challenging Crown authorizations and resource development on the basis of cumulative impacts and limit the scope of future potential development.

\section{Cumulative EnVironmental EfFects}

Cumulative environmental effects assessments are another way that cumulative impacts on Aboriginal and treaty rights have been addressed, although these assessments have significant limitations. The federal government and many Canadian provinces have enacted EA legislation mandating the assessment of cumulative environmental effects for projects requiring EAs. These regimes operate independently of the duty to consult although they require consideration of certain impacts on Aboriginal rights and interests to varying degrees, whether secondary to environmental effects or more generally.

While there can be subject matter overlap with the duty to consult, EA processes and the duty to consult process are conceptually distinct. The duty to consult (and, where appropriate, accommodate) is focused on impacts to asserted or established Aboriginal or treaty rights. EAs are generally focused on environmental effects; these may include considerations of certain Aboriginal interests, but to date have not required rights-based impact assessments. In the case of cumulative environmental effects, there can be significant differences between what must be assessed vis-à-vis impacts to Aboriginal or treaty rights in comparison to the assessments required by the duty to consult, as detailed below.

Proponents need to be alive to these differences and cannot assume that meeting statutory EA requirements will also fulfill the duty to consult for several reasons. First, many decisions that trigger the duty to consult will not require a full EA, or meet a statutory requirement triggering a cumulative environmental effects assessment. Second, the current requirements for cumulative environmental effects assessments are focused on environmental effects and do not require rights-based impact assessments, with the exception of new federal and British Columbia legislation that is not yet in force. Third, the duty to consult may require greater accommodation of incremental cumulative impacts of the proposed project than that required by an EA process. Finally, the adequacy of consultation is typically reviewed by courts on a more stringent standard than applied to an EA decision. Consider a hypothetical government decision to approve a project having significant cumulative effects, which were assessed primarily through an environmental lens. A court on review could easily conclude that the EA decision was reasonable but that the duty to consult was not met as the process did not provide for adequate consultation or accommodation of impacts to affected Aboriginal or treaty rights. This scenario has occurred in several cases and the potential for this outcome highlights the importance of first understanding what is required by the constitutional duty to consult, and then looking to supplement this duty by any additional regulatory requirements, rather than simply relying on the latter without separately considering the former.

To illustrate some of the differences between the duty to consult and EA requirements, we have set out below a comparative analysis of the federal, Alberta, and British Columbia 
legislative regimes with a specific focus on Aboriginal peoples and interests and cumulative impacts. This considers requirements under the federal Canadian Environmental Assessment Act, 2012, ${ }^{84}$ the Alberta Environmental Protection and Enhancement Act, ${ }^{85}$ the British Columbia Environmental Assessment Act, ${ }^{86}$ and the British Columbia Cumulative Effects Framework. ${ }^{87}$ It also considers requirements under the new federal Impact Assessment Act, ${ }^{88}$ which received royal assent on 21 June 2019, and the new British Columbia Environmental Assessment Act, ${ }^{89}$ which received royal assent on 27 November 2018 . The IAA and New BC $E A A$ are not yet in force. The coming into force date for the $I A A$ has not yet been announced while the New BC EAA is expected to come into force in late 2019.

\section{A. ASSESSMENT OF Aboriginal INTERESTS}

The situations in which EAs are required and the degree to which Aboriginal interests need to be assessed vary widely under current federal, Alberta, and British Columbia EA legislation (which does not include the federal IAA and New BC EAA that are not yet in force) ${ }^{90}$ While each regime has broad assessment requirements, only the current federal CEAA 2012 regime prescribes specific Aboriginal interests that need to be separately assessed. ${ }^{91}$ This includes impacts from a change caused to the environment ${ }^{92}$ on Aboriginal peoples, with respect to their:

- $\quad$ health and socio-economic conditions;

- $\quad$ physical and cultural heritage;

- $\quad$ current use of lands and resources for traditional purposes; or

84 SC 2012, c 19 [CEAA 2012].

85 RSA $2000, \mathrm{c} \mathrm{E}-12$ [EPEA].

86 SBC 2002, c 43 [BC EAA].

87 Province of British Columbia, "Cumulative Effects Framework," online: <www2.gov.bc.ca/gov/content/ environment/natural-resource-stewardship/cumulative-effects-framework> [CE Framework].

88 Bill 69, An Act to enact the Impact Assessment Act and the Canadian Energy Regulator Act, to amend the Navigation Protection Act and to make consequential amendments to other Acts, 1st Sess, 42nd Parl, 2019 (assented to 21 June 2019), SC 2019, c 28 [IAA].

$89 \quad$ Supra note 27.

90 CEAA 2012, supra note 84, contains a Designated Project List, which prescribes the projects that require EAs. Any project listed in the federal Regulations Designating Physical Activities, SOR/2012-147, must undergo a federal EA. These include oil refineries, oil sands mines, coal mines, and electrical generating facilities meeting certain capacity thresholds or being located in wildlife areas or sanctuaries. The IAA will similarly include a designated project list and the CEAA has recently issued a discussion paper on the proposed project list. The current BC EAA and the Alberta EPEA also have regulations setting out the projects that require environmental assessment although the list of projects is different. See Reviewable Projects Regulation, BC Reg 370/2002, and the Environmental Assessment (Mandatory and Exempted Activities) Regulation, Alta Reg 111/1993.

91 The Alberta EPEA, supra note 85, has no separate requirements to consider impacts on Aboriginal interests although certain Aboriginal interests would be captured under the general EA requirements. These requirements include the need to provide "a description of potential positive and negative environmental, social, economic and cultural impacts of the proposed activity, including cumulative, regional, temporal and spatial considerations" and an analysis of the significance of these potential impacts (ibid, s 49(d)). The BC EAA, supra note 86, provides certain procedural requirements where a reviewable project impacts treaty lands, but this has limited application as most areas in the province are not covered by treaties. It also confirms that a reviewable project may not proceed on treaty lands without the consent of the treaty First Nation if the final agreement requires this consent (ibid, s 29.1).

92 "Environment" is defined in CEAA 2012, supra note 84, as the "components of the Earth, and includes (a) land, water and air, including all layers of the atmosphere; (b) all organic and inorganic matter and living organisms; and (c) the interacting natural systems that include components referred to in paragraphs (a) and (b)" (s 2(1)). 
- $\quad$ any structure, site, or thing that is of historical, archaeological, paleontological, or architectural significance..$^{93}$

Although some of these items and interests may overlap with Aboriginal and treaty rights, CEAA 2012 notably does not specifically require an assessment of impacts to Aboriginal or treaty rights, and the impacts being assessed all require an underlying biophysical change to the environment (such as a decrease in fish leading to a potential impact on traditional harvesting activities). If there is no biophysical impact, impacts on Aboriginal or treaty rights or impacts to Aboriginal peoples generally are not considered.

The federal IAA and the New BC EAA broaden the scope of assessment significantly to include consideration of impacts of proposed projects on Aboriginal and treaty rights and Aboriginal peoples generally. This includes impacts on their health, social, and economic conditions, irrespective of the presence or absence of biophysical effects or an impact to Aboriginal or treaty rights. These considerations extend beyond the current scope of the duty to consult, which does not look at impacts to Aboriginal peoples generally. For example, the IAA stipulates specific factors relating to Aboriginal peoples that must be taken into account in an impact assessment, including:

- the impact that the designated project may have on any Indigenous group and any adverse impact that the designated project may have on the rights of Indigenous peoples of Canada recognized and affirmed by section 35 of the Constitution Act, 1982;

- Indigenous knowledge $\mathrm{e}^{94}$ provided with respect to the designated project;

- $\quad$ considerations related to Indigenous cultures raised with respect to the designated project;

- $\quad$ any assessment of the effects of the designated project that is conducted by or on behalf of an Indigenous governing body and that is provided with respect to the designated project; and

On 16 May 2019, the Government of Canada released a Discussion Paper for an Indigenous Knowledge Policy Framework. The Framework will help guide the implementation of the Indigenous knowledge provisions in the legislation proposed under Bills C-68 and C-69 and is intended to provide an overarching, principles-based approach for the consideration and protection from unauthorized disclosure of confidential Indigenous knowledge in the context of the Bills. See Government of Canada, Discussion Paper: Indigenous Knowledge Policy Framework for Proposed Project Reviews and Regulatory Decisions (Ottawa: Government of Canada, 2019), online: <canada.ca/content/dam/themes/ environment/conservation/environmental-reviews/ik-discussion-paper-en.pdf $>$. 
- $\quad$ any study or plan conducted or prepared by an Indigenous governing body not otherwise referred in respect of a region related to the designated project and that has been provided with respect to the project. ${ }^{95}$

Under the New BC EAA, ${ }^{96}$ whenever an EA is required, the effects of a proposed project on "Indigenous nations" ${ }^{\text {"97 }}$ and their Aboriginal or treaty rights must be assessed, ${ }^{98}$ as well as whether the project is consistent with any land-use plans of an Indigenous nation. ${ }^{99}$ These considerations are in addition to the more general requirement to consider the positive and negative direct and indirect effects of the project, including environmental, economic, social, cultural, and health effects, and adverse cumulative effects. The Environmental Assessment Office (EAO) is also directed to use Aboriginal knowledge in decision-making under the New $\mathrm{BC} E A A,{ }^{100}$ but there is no further explanation given as to how this knowledge is to be considered.

Another notable new requirement under the New BC EAA - which does not exist in the federal IAA - is that the British Columbia EAO will be required to seek to achieve consensus with participating Indigenous nations on its recommendation regarding whether an EA certificate should be issued, and for how long. ${ }^{101}$ If consensus cannot be reached, the responsible Ministers must offer to meet with the Indigenous nation to attempt to achieve consensus. If consensus cannot be reached and the responsible Ministers still decide to issue an EA certificate, the Ministers must provide reasons. ${ }^{102}$ The New BC EAA also provides for the availability of an alternative dispute resolution process for numerous determinations under the Act. ${ }^{103}$ The New BC EAA also specifically requires the consent of an Indigenous nation where it is required by a treaty or by another agreement between the British Columbia

IAA, supra note 88, ss 22(1)(a)(ii), (c), (g), (1), (q), (r). The IAA uses the term "Indigenous" instead of "Aboriginal," but it is defined to mean the Aboriginal peoples of Canada as set out in section 35(2) of the Constitution Act, 1982, supra note 1. "Indigenous governing body" is defined in the IAA, ibid, as "a council, government or other entity that is authorized to act on behalf of an Indigenous group, community or people that holds rights recognized and affirmed by section 35 of the Constitution Act, 1982 " (s 2).

96 Supra note 27. An EA must be conducted if the EAO does not exercise its powers under section $16(2)$ (b) to recommend an order exempting a project be issued or under section $16(2)(\mathrm{c})$ to recommend an order terminating the project be issued. The scope and process of the EA are determined by the EAO or referred by the EAO, with recommendations, to the Minister (ibid, s 18(1)). Section 16(2)(b) provides that if the EAO considers that the project will not have a significant adverse environmental, economic, social, cultural, or health effect, or will not have serious effects on an Aboriginal nation or section 35 rights, the EAO must refer the project to the Minister with a recommendation that an order exempting the project from an EA be issued. Conversely, section 16(2)(c) provides that if the EAO considers that the project will have extraordinarily adverse effects generally or on an Aboriginal nation or section 35 rights; will have extraordinarily adverse effects on a prescribed protected area; is, on the advice of the Minister or another Minister, clearly incompatible with a government policy; or is substantially the same as a project that has previously been the subject of a termination order, the EAO must refer the project to the Minister with a recommendation that an order terminating the project be issued. The New BC EAA, supra note 27 , does not define the term "Indigenous nation."

Ibid, $\mathrm{s} 25(1)$.

Ibid, ss $25(2)(\mathrm{a}),(\mathrm{g})$.

Ibid, s 2(2)(b)(i)(C).

Ibid, s 29(3).

Ibid, s 29(7).

See ibid, $\mathrm{s}$ 5. This includes a determination by the EAO that there is no reasonable possibility an Aboriginal Nation or its constitutionally entrenched rights will be adversely affected by a project, a decision by the responsible Minister to exempt a project from the environmental assessment process, an order by the responsible Minister that a project may not proceed as proposed, an EA process order issued by the EAO (including the determined scope, assessment plan, and information requirements), and a decision regarding the application for an EA certificate. 
government and the Indigenous nation. ${ }^{104}$ These new consensus-based requirements appear to be aimed at incorporating UNDRIP principles of "free, prior and informed consent" into the EA process, although it is not an absolute requirement other than in the two instances described above, which already existed prior to the New BC EAA.

\section{B. Assessment of Cumulative ENVIRONMENTAL EFFECTS}

The scope of activities reviewed for cumulative environmental effects assessments under federal and provincial EA legislation is significantly broader than that considered in relation to the duty to consult.

In addition to considering the impacts of a particular project in the context of past and cumulative impacts, cumulative environmental impact assessments must also typically consider impacts from other certain and reasonably foreseeable future projects. Under current federal guidance for CEAA 2012, "certain" is defined as an activity that will proceed or has a high probability of proceeding and "reasonably foreseeable" is defined as a physical activity that is expected to proceed. ${ }^{105}$ This guidance indicates that certain or reasonably foreseeable activities may include:

- $\quad$ future projects that have received approval (in whole or in part);

- $\quad$ projects that have been officially announced by a proponent;

- $\quad$ projects for which site preparation is being undertaken, which are under construction, under regulatory review, or about to be submitted for review;

- $\quad$ projects or activities directly associated with the project under review or induced if the project under review is approved; and

- $\quad$ projects identified in a development plan for the area. ${ }^{106}$

The scope of cumulative environmental effects assessments under British Columbia and Alberta legislation is similar. Under the current BCEAA, assessment of potential cumulative environmental effects may be required in an EA, but only if so ordered by the Director. ${ }^{107}$ This includes assessment of the effects of a proposed project after mitigation and how those

Ibid, s 7 .

105 Canadian Environmental Assessment Agency, Assessing Cumulative Environmental Effects under the Canadian Environmental Assessment Act, 2012 (Ottawa: Minister of the Environment, 2015) at 4, online: <ceaa-acee.gc.ca/Content/1/D/A/1DA9E048-4B72-49FA-B585-B340E81DD6AE/Cumulative \%20Effects\%20OPS\%20-\%20EN\%20-\%20March\%202015.pdf>.

106 See e.g. Canadian Environmental Assessment Agency, Assessing Cumulative Environmental Effects under the Canadian Environmental Assessment Act, 2012 (Ottawa: Canadian Environmental Assessment Agency, 2018), online: <publications.gc.ca/collections/collection_2018/acee-ceaa/En106-204-2018eng.pdf >; Alberta Energy and Utilities Board et al, Cumulative Effects Assessment in Environmental Impact Assessment Reports Required under the Alberta Environmental Protection and Enhancement Act, online: <open.alberta.ca/dataset/ffb3a8b8-8eab-421f-98aa-56f21dc98dbe/resource/a87805b5-96c445 a8-8899-92 fafa3b0503/download/cumulativeeffectseiareportsunderepea-a.pdf $>$ [Cumulative Effects Assessment]. 
project effects may combine with the effects of other past, present, and reasonably foreseeable projects and activities. ${ }^{108}$ The Alberta EPEA requires a description of potentially cumulative impacts and an assessment of their significance, unless otherwise ordered by the Director. ${ }^{109}$ This is similarly defined by provincial policy to include "the changes to the environment caused by an activity in combination with other past, present, and reasonably foreseeable human activities." 110

The current BC EAA is supplemented by the CE Framework, which was introduced in 2014 as a way to conduct regional assessments of cumulative effects in the province and support consideration of impacts to Aboriginal and treaty rights and interests. The $C E$ Framework is currently focused on five priority values (including old growth forest, aquatic ecosystems, grizzly bear, forest biodiversity, and moose ${ }^{111}$ ), which were selected based on a number of criteria including their importance to First Nations and the exercise of Aboriginal or treaty rights. ${ }^{112}$ Further values are expected to be added to the CE Framework in the future. While it provides certain support to the current BCEAA, it is still in the process of being implemented and is a tool to guide decision-making with no legislative requirement to consider its data, objectives, and thresholds. It is also unclear how it will effectively support and monitor the management of cumulative effects across the various provincial ministries responsible for managing British Columbia's natural resources. ${ }^{113}$

Cumulative effects must also be considered under the New BC EAA and the federal IAA. It is anticipated that assessments under these regimes will need to consider cumulative impacts to Aboriginal peoples and their Aboriginal or treaty rights, although the New BC EAA does not explicitly stipulate this requirement. ${ }^{114}$ Similar to current EA requirements, it is expected that these assessments will need to consider impacts from existing and reasonably anticipated activities.

The differences in the scope of activities being assessed have important implications when combined with the differing standards for accommodation (pursuant to the duty to consult)

Environmental Assessment Office, Information Bulletin \#1: Relationship between the Cumulative Effects Framework and Reviewable Project Environmental Assessment (Victoria: EAO, 2017), online: $<$ www2.gov.bc.ca/assets/gov/environment/natural-resource-stewardship/cumulative-effects/bulletin_1 cef-ea feb 2017.pdf $>$. EPEA, supra note 85 , ss 49(d)-(e).

Cumulative Effects Assessment, supra note 106 at 2. The policy states that "reasonably foreseeable projects" include the following types of projects unless there is a particular circumstance to warrant their exclusion: (i) "approved," (ii) "currently undergoing regulatory review," (iii) "about to be submitted for review," (iv) "officially announced by a proponent," (iv) "directly associated with the project under review," (v) "not directly associated, but induced if the project is approved," and (vi) "identified in a development plan for the area" (ibid at 4).

111 Environmental Assessment Office, supra note 108

112 Province of British Columbia, Cumulative Effects Framework: Interim Policy (Victoria: National Resources Board, 2016) at 15.

113 In 2015, British Columbia's Auditor General conducted an audit to determine whether the provincial government and the Ministry of Forests, Lands \& Natural Resource Operations (FLNRO) have established a sound basis for managing cumulative effects to the environment. In its report entitled Managing the Cumulative Effects of Natural Resource Development in B.C. (Victoria: Office of the Auditor General of British Columbia, 2015) [AG Report], the Auditor General concluded that FLNRO had not been adequately addressing cumulative effects in its natural resource use decisions in northwestern British Columbia, where the Auditor General conducted its review. For FLNRO and other ministries to effectively manage cumulative effects, the Auditor General found that the government must clarify how its social, economic, and environmental expectations apply to managing Crown land. Government must then determine how the assessment framework will be used to support decisions. IAA, supra note 88 , ss 22(1)(a)(ii), (c); New BC EAA, supra note 27, s 25(a). 
and mitigation (within an EA). This is particularly the case for the proposed expansive new approaches to the consideration of Aboriginal interests under the IAA and the New BC EAA. Mitigation measures under EA processes must generally identify feasible measures that would mitigate significant adverse cumulative environmental effects. While mitigation may include avoidance and offset measures, it is often limited to measures that reduce but do not avoid significant adverse cumulative environmental effects.

By contrast, the duty-to-consult cases that have considered accommodation for cumulative impacts to Aboriginal and treaty rights to date have focused on avoiding or offsetting any additional cumulative impacts and not just minimizing such impacts. While it remains to be seen whether this will become a general trend, this potential heightened requirement, and the greater scrutiny that courts tend to apply when reviewing the duty to consult, underscores the importance of clearly delineating the additional incremental contribution of the current Crown decision at issue to existing cumulative impacts on Aboriginal and treaty rights.

As a result, it would be prudent for proponents and governments to conduct separate analyses of cumulative impacts for duty-to-consult (and accommodate) purposes and for EA purposes to ensure that the relevant duty-to-consult sphere of impacts is considered when determining whether and to what degree accommodation is required. It is important to understand which specific impacts may give rise to a requirement to avoid or offset, even though the proponent may choose to avoid or offset other impacts that go beyond those required by the duty to consult. This will be even more important under the New BC EAA and the federal $I A A$ given that the assessments will likely need to consider cumulative environmental effects on Aboriginal peoples generally.

\section{Strategic AsSessments}

In addition to cumulative environmental effects assessments, certain EA regimes provide for strategic or regional assessments. For example, CEAA 2012 permits the responsible Minister to establish a committee to study the effects of existing or future physical activities carried out in a region that is entirely on federal lands, or a joint committee with another jurisdiction to study the effects of existing or future physical activities carried out in a region that contains some or no federal lands. ${ }^{115}$ The new federal $I A A$ includes substantively identically worded provisions, ${ }^{116}$ but also provides for a new power to conduct strategic assessments of any issue or Government of Canada policy, plan, or program (proposed or existing) relevant to environmental impact assessments. ${ }^{117}$

Examples of strategic assessments at the provincial level include: (1) the intended approach under the Alberta Land Stewardship Act, ${ }^{118}$ the statutory instrument to implement Alberta's Land-use Framework ${ }^{119}$ and its Integrated Resource Management Systems, and (2)

CEAA 2012, supra note 84 , ss $73-74$.

IAA, supra note 88 , ss $92-93$.

Ibid, s 95.

SA 2009, c A-26.8 [ALSA].

Government of Alberta, Land-use Framework (Edmonton: Government of Alberta, 2008), online: $<$ open.alberta.ca/dataset/30091176-f980-4f36-8f5a-87bc47890aa8/resource/bc4b3fac-5e59-473b-9a991a83970c28e7/download/4321768-2008-land-use-framework-2008-12.pdf $>$ [Land-use Framework]. The Land-use Framework is premised on the implementation of cumulative effects management on a regional level to manage the impacts of development on land, water, and air. The Land-use Framework 
the Regional Strategic Environmental Initiative in British Columbia's Northeast region, a project in partnership with seven Treaty 8 First Nations (Blueberry River, Doig River, Halfway River, Prophet River, Saulteau, West Moberly, and McLeod Lake) and the Province of British Columbia. ${ }^{120}$

ALSA requires that all regulatory decisions in Alberta (including cumulative effects assessments pursuant to EPEA) comply with its requirements and those of the regional landuse plans created pursuant to it. ${ }^{121} A L S A$ is a kind of "super-legislation," insofar as it subordinates all other provincial laws and regulations to its regional planning provisions, ${ }^{122}$ and allows for the creation of regional plans that must be adhered to by provincial decisionmaking bodies. ${ }^{123}$ In so doing, it establishes the legal basis for implementation of the key strategies and priorities identified within the Land-use Framework "to manage public and private lands and natural resources to achieve Alberta's long-term economic, environmental and social goals." ${ }^{\prime 24}$ By going beyond a project-by-project analysis with the creation of region-based land-use planning, ALSA and the Land-use Framework seek, among other things, to incorporate cumulative effects management into all land-use decisions and to include First Nations and Métis organization in the consultation process. ${ }^{125}$ The Land-use Framework states that cumulative effects management "will be used in regional plans to manage the combined impacts of existing and new activities within the region" subject to a caveat that the emerging practice of cumulative effects management is an "emerging practice, an art not a science ... [to] be used pragmatically not dogmatically."126

One of the purposes of $A L S A$ is "to provide a means to plan for the future, recognizing the need to manage activity to meet the reasonably foreseeable needs of current and future generations of Albertans, including [A]boriginal peoples." ${ }^{27}$ The Land-use Framework divides Alberta into seven regional areas defined by seven watersheds, ${ }^{128}$ and it applies to both private and public lands. The Land-use Framework's approach and ALSA have been described as a move toward an ecosystem management approach to land management rather than a project-by-project approach in an attempt to respond to cumulative effects from current development in Alberta. ${ }^{129}$

notes that Alberta's environmental assessment system was traditionally done on a project-by-project basis, which worked at lower levels of development activities but is not effective in addressing the cumulative impacts of multiple developments.

Province of British Columbia, Regional Assessments - Northeast, online: <www2.gov.bc.ca/gov/ content/environment/natural-resource-stewardship/cumulative-effects-framework/regional-assessments/ northeast>.

ALSA, supra note 118, ss 20-22.

Ibid.

Bernard J Roth \& Rachel A Howie, "Land-Use Planning and Natural Resource Rights: The Alberta Land Stewardship Act" (2011) 29:4 J Energy \& Natural Resources L 471 at 477.

Land-use Framework, supra note 119 at 7.

See Alan Harvie \& Trent Mercier, "The Alberta Land Stewardship Act and its Impacts on Alberta's Oil and Gas Industry" (2010) 48:2 Alta L Rev 295 at 298-302 (Harvie and Mercier provide a succinct overview of the seven key strategies of the Land-use Framework which include: (1) creation of land-use regions and regional plans; (2) creation of the Land-use Secretariat to oversee land-use decisions and Regional Advisory Councils; (3) Cumulative Effects Management; (4) Conservation and Stewardship Strategies; (5) proportion of efficient use of land; (6) establishing information, monitoring, and knowledge systems; and (7) inclusion of Aboriginal groups in land-use planning).

Land-use Framework, supra note 119 at 3, 31 .

ALSA, supra note $118, \mathrm{~s} 1(2)(\mathrm{b})$.

Land-use Framework, supra note 119 at 19.

Maria Lavelle, "Ambiguity and the Amendments to the Alberta Land Stewardship Act" (2012) 49:3 Alta L Rev 579 at 583. 
Alberta's first regional plan, the Lower Athabasca Regional Plan, was released in 2012. ${ }^{130}$ LARP employed a cumulative effects management approach, noting that managing cumulative effects on air, water, land, and biodiversity is important to meeting the needs of Aboriginal communities that have constitutionally entrenched rights in the lower Athabasca area. ${ }^{131}$ The Joint Review Panel for the Jackpine Mine Expansion Project (the Review Panel) considered LARP within the context of a joint EA process pursuant to CEAA 2012 and Alberta's Responsible Energy Development Act. ${ }^{132}$ In its report, the Review Panel noted that LARP was "an excellent and important framework for beginning to introduce a more integrated regional approach.",133

However, the Review Panel also found that mitigations proposed by proponents for individual projects were not effective at avoiding significant adverse cumulative effects on traditional land use (TLU), ${ }^{134}$ as project effects, when taken together with the effects of historical, approved, and future projects in the surrounding region, were likely to result in significant adverse cumulative effects on Aboriginal rights, TLU, and culture. ${ }^{135}$ It also expressed concerns regarding the methods used by proponents to assess project and cumulative effects. ${ }^{136}$

LARP was criticized by participating Aboriginal groups, as noted by the Review Panel, because it:

- $\quad$ failed to address management of ongoing TLU;

- designated new conservation areas without considering the impact on the First Nations' TLU or whether such areas supported TLU;

- designated new tourism and recreation areas without considering the impact on First Nations' TLU;

- failed in its inclusion of Aboriginal peoples to be an effective or meaningful landuse planning tool;

- $\quad$ did not include or protect Aboriginal and treaty rights, TLU, or culture;

- $\quad$ was being applied by decision-makers and industry to preclude protection of Aboriginal and treaty rights and land use and ruled out the possibility of establishing areas that could be set aside for TLU and the exercise of Aboriginal and treaty rights; and

Government of Alberta, Lower Athabasca Regional Plan 2012-2022 (Edmonton: Government of Alberta, 2012), online: $<$ landuse.alberta.ca/landUse\%20Documents/Lower\%20Athabasca\%20Regional \%20Plan\%202012-2022\%20Approved\%202012-08.pdf> [LARP].

Ibid at 2 .

SA 2012, c R-17.3 [REDA].

Re Shell Canada Energy Jackpine Mine Expansion Project (9 July 2013), 2013 ABAER 011 at para 14, online: AER <aer.ca/documents/decisions/2013/2013-ABAER-011.pdf> [Joint Review Panel Report]. Ibid at para 36.

Ibid at para 34

Ibid at paras $22-23$. 
- $\quad$ prioritized economic interests over section 35 interests, and the government failed to meaningfully consult with the First Nations on the development of LARP. ${ }^{137}$

TLU management frameworks can include the specific measures to be taken in managing the long-term cumulative effects of development to achieve the goals identified in regional plans. The Review Panel noted that the absence of a management framework and associated thresholds for TLU made it very difficult for Aboriginal groups, industry, and review panels to evaluate the impact of individual projects on TLU. It further found that many of the proposed frameworks and thresholds set out in LARP were undeveloped and projects continued to be approved even as timelines for implementation were postponed.

On this basis, the Review Panel recommended that "Alberta develop and implement a TLU management framework for the Lower Athabasca region as a component of the LARP." 138 It additionally held that it was "critical that the frameworks, plans, and thresholds identified in the LARP be put in place as quickly as possible." 139 The need for a TLU management framework was echoed two years later in a 2015 review of LARP by a review panel appointed by the British Columbia Stewardship Ministers, further to requests from six First Nations. ${ }^{140}$ The panel was highly critical of its approach to cumulative effects management in meeting the needs of Aboriginal communities in the region and recommended the development and inclusion of a TLU management framework into LARP so as to effectively and meaningfully integrate the views of First Nations in the region. ${ }^{141}$ There has been no commitment to develop such a TLU Management Framework, and until such time as it is incorporated, LARP will likely not have a "super legislation" effect on provincial decision-makers. ${ }^{142}$

ALSA also affords wide-ranging and significant discretion to Cabinet in determining the scope and content of regional plans, including whether to incorporate elements essential to a cumulative effects management approach (such as thresholds, indicators, and details related to monitoring and policies). ${ }^{143}$ This latitude undermines its potential to address cumulative environmental impacts.

Even after the criticisms from the Joint Panel and a 2016 review following applications for review pursuant to section 19.2 of $A L S A$ by six First Nations, ${ }^{144}$ LARP has not been amended to incorporate additional tools to address Aboriginal and treaty rights as part of its land-use decision-making. Inclusion into LARP is required before regulatory decision-

Ibid; Nigel Bankes, Sharon Mascher \& Martin Olszynski, "Can Environmental Laws Fulfill their Promise? Stories from Canada” (2014) 6 Sustainability 6024 at 6029. Joint Review Panel Report, ibid at para 36.

Ibid at para 14 .

Athabasca Chipewyan First Nation; Mikisew Cree First Nation; Cold Lake First Nations; Onion Lake Cree Nation; Fort McKay First Nation, Fort McKay Métis First Nation, and Fort McKay Métis Community Association; and Chipewyan Prairie Dene First Nation.

Stewardship Minister Review Panel, Review Panel Report 2015: Lower Athabasca Regional Plan (Edmonton: Stewardship Minister, 2012) at 6, 183-84, online: <open.alberta.ca/dataset/5c910acf-9e8c46b5-b52d-60fc8bd2bbbd/resource/d9a6bff5-f9b5-45fe-81ed-a8de3492e271/download/2016-ReviewPanel-Report-2015-Lower-Athabasca-Regional-Plan-2016-06-22.pdf > [Review Panel Report].

Bankes, Mascher \& Olszynksi, supra note 137 at 6029.

Ibid at 6027; Harvie \& Mercier, supra note 125 at 315.

Supra note 118 . 
makers are required by legislation to consider the TLU management plan or other management plans aimed at addressing cumulative affects to Aboriginal and treaty rights.

One recent example is the Moose Lake Access Management Plan (MLAMP), which was scheduled to be approved by the Government of Alberta back in July $2018 .^{145}$ The draft Moose Lake Management Plan was prepared in collaboration with the Fort McKay First Nation and once finalized, was intended to establish resource development management requirements for Crown land within the ten-kilometre management zone neighbouring Moose Lake Reserves 174A and 174B. ${ }^{146}$ Once finalized, it was intended to be incorporated into the broader MLAMP and incorporated as a subregional plan into LARP.

The critical nature of being incorporated within LARP is underscored in a number of AER decisions including Prosper Petroleum. ${ }^{147}$ In its decision to approve Prosper Petroleum Limited's application pursuant to the Oil Sands Conservation Act ${ }^{148}$ to construct and operate a bitumen recovery scheme, the AER considered whether it must consider the MLAMP. The AER held that it could not adjourn its decision until MLAMP was finalized and incorporated into LARP and that

the panel is aware that the province has said it intends to finalize an access management plan for the Moose Lake area i.e. (MLAMP) and make it a LARP subregional plan. At the time of writing this decision, the $M L A M P$ has not been implemented as a $L A R P$ subregional plan. As a result, only the $L A R P$ and its regulatory details ... guide our decision. ${ }^{149}$

ALSA and regional land-use plans have not yet lived up to their full potential with reference to their ability to consider cumulative impacts on Aboriginal and treaty rights as part of land-use decision-making. If Cabinet discretion is exercised in a manner consonant with the purposes of ALSA and the Land-use Framework (and if a TLU Management Framework or MLAMP are incorporated), it may be able to provide a framework for cumulative impacts on Aboriginal and treaty rights to be considered in provincial decisions in landscape-level land-use planning.

Through British Columbia's Environmental Stewardship Initiative (ESI), the Province of British Columbia, industry, and First Nations are collaborating to develop new environmental stewardship projects associated with natural resource and infrastructure development. ${ }^{150}$ This

Government of Alberta, Draft Moose Lake $10 \mathrm{~km}$ Management Zone Plan (Edmonton: Government of Alberta, 2018), online: <talkaep.alberta.ca/5044/documents/9046>.

Ibid.

Supra note 71.

RSA 2000, c O-7.

Supra note 71 at para 38. See also Re TransCanada Pipelines Limited Applications for the White Spruce Pipeline Project Fort McKay Area (22 February 2018), 2018 ABAER 001 at para 38, online: AER $<$ aer.ca/documents/decisions/2018/2018ABAER001.pdf $>$ (the AER agreed with TransCanada Pipelines Limited that the AER is only required under section 20 of REDA, supra note 132, to act in accordance with LARP. While LARP is Alberta's vehicle to address cumulative effects in the Lower Athabasca region, it does not currently set any specific limits or thresholds related to the cumulative effects of development on Aboriginal rights. The AER found that as there is no other legislative or regulatory limits for cumulative impacts on Aboriginal rights and no evidence was provided to make a sound comparison of cumulative effects).

150 Province of British Columbia, "Environmental Stewardship Initiative," online: < www2.gov.bc.ca/gov/ content/environment/natural-resource-stewardship/consulting-with-first-nations/environmentalstewardship-initiative $>$ [BC, "ESI"]. 
initiative is enabled through agreements between participating First Nations and the Province of British Columbia. Four regional stewardship forums have recently been established in northern British Columbia to identify and develop projects according to priorities in each area. ${ }^{151}$ These agreements, which were all entered into in 2018 , provide frameworks to assess the state of identified valued ecosystems components, monitor ongoing impacts, identify restoration and enhancement opportunities, and potentially inform future decision-making. These initiatives are still in their early stages and thus too early to assess but will be important to monitor going forward.

Unlike the duty to consult, regional assessments provide a more comprehensive tool to address cumulative impact concerns by considering past, present, and future anticipated projects within an entire region rather than in the context of a more localized individual project or government decision. This approach would be especially useful in relation to assessments of impacts on Aboriginal or treaty harvesting rights, since relevant animal ranges commonly extend over a region and may be affected by a number of different projects or resource management decisions, the individual impacts of which might be relatively small.

The utility of this type of tool will rest on governments being willing to initiate regional assessments, as CEAA 2012, the federal IAA, and the New BC EAA do not contain any "trigger" provisions requiring that regional assessment occur in specified circumstances. ${ }^{152}$ It is also unclear what weight would be given to the results of such assessments by government decision-makers, or how they may be effectively incorporated into individual project planning or decision-making. As demonstrated by Alberta's ALSA, the level of discretion afforded to government in defining the scope of regional assessments will also affect its utility.

Other challenges have been that environmental management frameworks such as LARP have not been developed in a way that sufficiently considers Aboriginal and treaty rights and that the data gathered has not been incorporated into decision-making or made available to proponents. In order to meaningfully integrate Aboriginal views into resource management decisions, there needs to be more proactive groundwork for cumulative effects management. This includes the development of valued ecosystem components of particular concern for the exercising of Aboriginal and treaty rights, thresholds and targets, the identification of sensitive areas for the exercising of Aboriginal and treaty rights, and ways to ensure this data

151 See e.g. Province of British Columbia, Skeena Sustainability Assessment Forum and Indigenous Stewardship Projects Framework, 31 March 2018, [BC, Skeena] (between the Province of British Columbia, the Gitxsan, Gitanyow, Office of the Wet'suwet'en, Wet'suwet'en First Nation, Lake Babine Nation, Skin Tyee, Nee-Tahi-Buhn, Witset First Nation, and Hagwilget Village); Province of British Columbia, CSFN Omineca Demonstration Project Renewal Agreement, 8 June 2018, (between the Province of British Columbia, Nadleh Whut'en, Nak'azdli, Saik'uz First Nation, Setellat'en First Nation, Takla Lake First Nation, Tl'azt'en Nation, Ts'il Kaz Noh First Nation (Burns Lake Indian Band), and Carrier Sekani Tribal Council); Province of British Columbia, Modification Agreement: North Coast Cumulative Effects Demonstration Project Agreement, 31 March 2018, (between the Province of British Columbia, Gitxaala First Nation, Gitga'at First Nation, Kitselas First Nation, Kitsumkalum Indian Band, and Metlanktla First Nation). A more complete list of agreements is available at the BC, "ESI," ibid. See Canadian Bar Association, Environmental Assessment Process Review” (Ottawa: CBA, 2016), online: <letstalkea.ca/3524/documents/6567>; West Coast Environmental Law et al, "A Blueprint for Revitalizing Environmental Assessment in British Columbia" (Victoria: West Coast Environmental Law, 2018), online: <wcel.org/sites/default/files/publications/2018-04-blueprintforrevitalizing eainbcfinal-v2.pdf $>$ on the significance and utility of trigger provisions. 
is incorporated into decision-making and made available to proponents in the early design phase of a project.

\section{OUTSTANDING ISSUES AND Charting a BetTer PATh Forward}

It is evident from a review of Canadian case law and current and proposed EA regimes that numerous questions and challenges remain regarding the assessment of cumulative impacts on Aboriginal and treaty rights in project reviews. These challenges highlight why project reviews are not equipped to adequately address this issue and should not be expected to do so. ${ }^{153}$

The issue of cumulative impacts transcends individual projects and cannot be resolved piecemeal through project reviews and individual permitting decisions. In our view, the approach taken by some governments to simply broaden the scope of project reviews and make them more inclusive is not an effective solution, nor is it fair to either Aboriginal groups or proponents. This is not to say, however, that there is no role for cumulative impact assessments in project reviews - they are important considerations in EAs and the Supreme Court of Canada has indicated that they can provide context to better understand the potential degree of impact on Aboriginal or treaty rights within the duty to consult.

However, to truly address concerns of Aboriginal groups and to promote responsible development and decision-making, this issue needs to be dealt with in a more comprehensive way beyond individual project reviews. It must also be done in a way that does not create unintended consequences such as stifling investment in Canada due to unworkable, lengthy, and uncertain regulatory regimes for resource development and energy projects.

Below are some of our recommendations for improving the manner in which cumulative impacts are addressed by both governments and proponents. While more work is needed by government to develop coordinated and workable approaches and provide policy direction to Crown decision-makers, it is recognized that in the interim, much of the heavy lifting of both the duty to consult and EAs will be carried out by proponents during project reviews.

\section{A. Utilization of Land-Use Planning AND REgional ASSESSMENTS}

Governments have the tools to better address these issues but unfortunately are not using them effectively. Broader action by the federal, provincial, and territorial governments is needed, particularly in the area of effective land-use planning and strategic and regional assessments outside of individual project reviews. Regional cumulative impact assessments and more inclusive land-use planning are needed in areas of significant project development, which can identify areas where development may be able to proceed and areas that need to be protected from an environmental and Aboriginal perspective. As noted by the NEB in 
Westcoast, regional assessments can also be used to establish acceptable thresholds, based on past impact and future trends and proposals, which can be drawn upon by subsequent project reviews in the region. ${ }^{154}$ It remains to be seen whether the tools in the federal IAA, including regional assessments, and in British Columbia's approach, including the $C E$ Framework and stewardship agreements, will be sufficiently workable models and whether the data gathered will be incorporated into decision-making. Should the Alberta ALSA model be adopted, a careful analysis of the proposed discretion afforded to Cabinet or the executive to implement such a model should be conducted to ensure such discretion does not ultimately change the outcomes of the intended policy and legislative changes. ${ }^{155}$

There must also be measures in place to ensure that Aboriginal groups are included in these processes. This is not only of practical importance to obtain input at the earliest stages of land-use planning, but because such processes in and of themselves may trigger a duty to consult. The Supreme Court of Canada in Rio Tinto stated that strategic, higher-level decision-making can also trigger the duty to consult where Aboriginal rights and interests may be affected.

As part of this, more information needs to be gathered and consolidated on Aboriginal traditional land use and valued ecosystem components, and this information needs to be incorporated into future assessments. There is significant information on Aboriginal traditional land use and valued ecosystem components, but it has not been consolidated by provincial and federal governments in a useable manner. While confidentiality issues will prevent broad dissemination of this information, the federal and provincial governments should work with Aboriginal groups to ensure that their respective information is readily available to decision-makers with appropriate confidentiality protections in place. Proponents should also be able to access information to the extent permissible without breaching confidentiality or be able to learn about sensitive areas to avoid, in order to assist in early feasibility and project planning.

In addition to existing information, there is further work required to identify and monitor valued ecosystem components that are needed in order for Aboriginal groups to meaningfully exercise their Aboriginal and treaty rights. This includes not only identifying the valued ecosystem components but also assessing their current condition and tolerance for change. The British Columbia government is undertaking some work in this area through its Environmental Stewardship Initiative referenced above, wherein they are working with certain First Nations to develop agreed-upon environmental valued components and monitoring programs to assess the state of those valued components and identifying and implementing associated stewardship initiatives. ${ }^{156}$ This is promising work, but it remains to be seen how it will be implemented and specifically how the data collected will be incorporated in future regional plans and project reviews. 


\section{B. Addressing Aboriginal Concerns \\ OUTSIDE OF THE CONSULTATION AND Project Review Setting}

It would also be valuable for governments to create separate forums to address common cumulative impact concerns of Aboriginal groups in certain regions, particularly with respect to certain at-risk species. In other words, there needs to be more off-ramps in regulatory processes where specific concerns regarding cumulative impacts on Aboriginal or treaty rights that transcend the project and cannot be addressed within a single project review are identified early on and discussed and addressed through other forums.

This is needed because Aboriginal groups are focused not just on avoiding further cumulative impacts but rather addressing past cumulative impacts and ensuring that they have a sufficient ability to exercise their asserted or established Aboriginal rights. These concerns falling outside the scope of the duty to consult can often overtake discussions about the impacts of the Crown decision at issue, impeding productive discussions and information sharing.

Broader action by governments would also help to resolve the common issue of inadequate statutory mandates of certain government decision-makers and tribunals that may not be equipped to address the issues that are raised in consultation — issues for which the Crown may still be responsible to consider in order to fulfill the duty to consult.

\section{Clearer GUIDANCE From GOVERNMENT TO FILL IN KNOWLEDGE GAPS}

Within the consultation framework, given the divergences and unanswered questions in the case law, it would also be beneficial for governments to provide greater policy or regulatory guidance on matters including:

- the respective roles and responsibilities for government and proponents in identifying and assessing cumulative impacts on Aboriginal or treaty rights;

- $\quad$ how cumulative impacts should be assessed, how cumulative impact assessments should be prepared, and best practices related thereto;

- how Aboriginal knowledge should be incorporated and considered in such assessments;

- the reciprocal obligations of Aboriginal groups in raising cumulative impact concerns, including the type of information that is needed to support cumulative impact concerns and the assessment of how the project may further contribute to those impacts; and

- what types of accommodation measures would be appropriate in a particular situation, if required. 


\section{RECOMMENDATIONS FOR PROPONENTS FOR CONSIDERING CUMULATIVE IMPACTS in CONSUltation}

Regardless of whether governments take action to address this prevalent issue, the case law is clear that meaningful consultation requires engagement with Aboriginal groups on cumulative impact concerns if the duty to consult is triggered and the concerns are relevant to the project at issue. Often, this task will be delegated by the Crown to proponents. This engagement needs to be focused on understanding how Aboriginal or treaty rights have been impacted by past cumulative impacts; how the decision at issue may further contribute to this impact; and what may be done to avoid, offset, or minimize the impact. This includes answering questions such as:

- What Aboriginal or treaty rights are currently being exercised in the vicinity of the project?

- How has the ability to exercise these rights been affected by cumulative impacts?

- What are the resources needed to meaningfully exercise rights that may be impacted by the project, and what are the specific impacts?

- Is the area or resources impacted by the project of particular significance to the Aboriginal group for exercising its Aboriginal or treaty rights?

- What other areas are still available to the Aboriginal group to exercise its Aboriginal or treaty rights?

- Have there been previous developments in this area, and how have they impacted Aboriginal or treaty rights? Have there been similar developments in other areas of the Aboriginal group's traditional territory, and if so, how have those developments impacted Aboriginal or treaty rights?

- $\quad$ Are there any specific initiatives that can be undertaken to address cumulative impacts on Aboriginal or treaty rights of the Aboriginal group at issue?

- What additional incremental impact will the project have? What is the nature of the impact in terms of magnitude, duration, frequency, reversibility, and probability of occurrence - during each phase of construction, operation, and decommissioning?

- How can this incremental impact be avoided, offset, or minimized?

- What review processes and monitoring initiatives are needed to ensure measures have been properly implemented?

This is a non-exhaustive list as the questions may vary depending on the nature of the proposed project at issue, the degree of past development in the area, and the perspective of the Aboriginal group that is potentially affected. Ultimately, in order to achieve meaningful 
consultation in dealing with cumulative effects concerns, there must be a dialogue to better understand the concerns and to exchange sufficient information to enable the Crown (which is ultimately responsible for ensuring the adequacy of consultation) to effectively and meaningfully assess cumulative impacts on Aboriginal and treaty rights in its decisionmaking.

It must be recognized that the issue of cumulative impacts cannot be resolved in any one project review, and there may be divergences of opinion between proponents, the Crown, and Aboriginal groups about the degree of potential impacts given the state of existing development. That said, attempts to bridge these differences during consultation, where possible and reasonable, may be helpful in improving the overall relationship between the proponent and the affected Aboriginal group(s) and in avoiding contributing to an issue that is of significant concern for many Aboriginal groups. 